February 2019

\title{
On the Heterogeneous Welfare Gains and Losses from Trade $^{1}$
}

\author{
Daniel Carroll
}

Federal Reserve Bank of Cleveland

daniel.carroll@clev.frb.org

Sewon Hur

Federal Reserve Bank of Cleveland

sewon.hur@clev.frb.org

\section{[PRELIMINARY AND INCOMPLETE]}

\begin{abstract}
How are the gains and losses from trade (disruptions) distributed across individuals within a country? First, we document that tradable goods constitute a larger fraction of expenditures for poor households. Second, we build a trade model with nonhomothetic preferences - to generate the documented relationship between tradable expenditure shares, income, and wealth - and uninsurable earnings risk - to generate heterogeneity in income and wealth. Third, we use the calibrated model to quantify the differential welfare gains and losses from trade on households along the income and wealth distribution. In a numerical exercise, we increase trade costs by 20 percentage points and allow the economy to transition to a new steady state. We find that households in the lowest wealth decile experience welfare losses over the transition, measured by permanent consumption equivalents, that are 35 percent larger than those in the highest wealth decile. Finally, we find that the distributional impacts of trade significantly depend on how the tariff revenue is spent. In particular, using tariff revenue to reduce labor income taxes is close to welfare-neutral.
\end{abstract}

KEYWORDS: trade wars, trade gains, inequality, consumption, optimal taxation JEL CLASSification CODES: E21, F10, F62, H21

\footnotetext{
${ }^{1}$ We thank Michael Jenuwine for outstanding research assistance. The views expressed herein are those of the authors and not necessarily those of the Federal Reserve Bank of Cleveland or the Federal Reserve System. This paper is being prepared for the Carnegie-Rochester Conference Series on Public Policy. First draft: January 2019.
} 


\section{Introduction}

How are the gains and losses from trade (disruptions) distributed across individuals within a country? On one hand, many researchers have argued that increased trade- especially with China-has contributed to the decline in manufacturing jobs in the U.S. over the last two decades. For example, Autor et al. (2013) find that import competition from China has contributed to a quarter of the job losses in U.S. manufacturing from 1990 to 2007. On the other hand, trade can lead to increased efficiency and lower the price of consumption. If tradable goods constitute a larger fraction of consumption expenditures for poor households, then they may realize disproportionately larger gains from trade. Fewer studies have analyzed how trade, through its effect on the price of tradable goods, affects the distribution of welfare gains across income and wealth.

Our paper makes four main contributions to the literature. First, we document heterogeneity in tradable consumption expenditures across the income and wealth distribution. We find that tradable expenditure shares are decreasing in both income and wealth. Second, we build a trade model with uninsurable income risk and non-homothetic preferences which generates both heterogeneity in income and wealth as well as the documented relationship between income, wealth, and tradable expenditure shares. While each of these features has been studied in isolation, we are the first to investigate their interaction in the trade literature. Third, we use the calibrated model to quantify the differential welfare gains and losses from trade on households along the income and wealth distribution. Finally, we find that the distributional impacts of trade significantly depend upon how tariff revenue is spent. In particular, if tariff revenue is used to reduce labor income taxes, then increasing tariffs can be close to welfare-neutral by benefiting the poor at the expense of the wealthy.

In the first part of this paper, we document that tradable goods constitute a larger fraction of expenditures for poor households. Using the Panel Survey of Income Dynamics and the Consumer Expenditure Survey, we show that households in the lowest wealth decile spend 38 percent of their consumption expenditures on tradable goods, compared to 30 percent for those in the highest wealth decile. Similarly, households in the lowest and highest income deciles spend 37 and 30 percent, respectively, of their consumption expenditures on tradables. These relations are robust to controlling for a variety of household characteristics such as 
age, household size, education, and home ownership.

Next, we build a model to analyze the heterogeneous impacts of trade along the income and wealth distribution. Specifically, we extend the classic Ricardian model of trade (Dornbusch et al. 1977) in two dimensions. First, households derive utility from the consumption of a homogeneous non-tradable good and a continuum of tradable goods according to Stone-Geary non-homothetic preferences so that poor households have a higher tradable expenditure share. Second, we depart from the representative agent framework by introducing households who face uninsurable income risk in each country. We calibrate the model to match features of the income and wealth distribution in the U.S. as well as the relation between tradable consumption shares and wealth that we document in the empirical section.

We use the calibrated model to compute the distribution of welfare losses along a transition from a symmetric steady-state equilibrium with low trade costs to one with trade costs that are 20 percentage points higher. As our baseline, we assume that any additional tariff revenue is used to finance additional wasteful government expenditure. We find that welfare losses are large and that they vary significantly with income and wealth. Households in the lowest wealth decile experience welfare losses, measured by permanent consumption equivalents, that are 35 percent larger than those in the highest wealth decile.

Why do poor households suffer larger welfare losses from increasing trade costs? The source of the disparity can be decomposed into three channels. The first is the expenditure channel. Tariffs lead to a rise in the price of tradable goods as the increase in the effective price of foreign inputs induces a reallocation of production within tradable varieties from more efficient foreign firms to less efficient domestic counterparts. ${ }^{2}$ As a result, poor households, who spend a larger share of expenditures on tradable goods, suffer larger welfare losses.

When tradable goods are also an input into capital production, a higher tradable price increases the price of investment as well. In an environment with incomplete asset markets, this benefits wealthy households because they are typically sellers of capital and hurts highwage, low-wealth households, who are buyers of capital. We refer to this as the investment

\footnotetext{
${ }^{2}$ This is consistent with Broda and Romalis (2008), Amiti et al. (2018), Bai and Stumpner (2018), and Jaravel and Sager (2018) who document that increased import competition from China has resulted in lower prices of tradable goods.
} 
channel. A higher investment price leads to capital shallowing, which over time results in a lower wage and, eventually, a higher return on capital. This movement in factor prices hurts low wealth households because they derive most of their income from labor - this is the factor price channel. Notice that all three channels hurt low wealth households.

In the final part of the paper, we explore the extent to which increasing trade distortions (i.e. tariffs) can be used to offset other distortions, such as labor and capital income taxes, and how these alternative scenarios change the distribution of welfare gains and losses from trade disruptions. Across these scenarios, the expenditure and investment channels are the same as in the baseline as we show that the effect on the tradable and investment prices depend only on the total trade distortion. Using additional tariff revenue to reduce capital income taxes is the most efficient scenario, increasing consumption and output, but still leads to an average welfare loss of 0.25 percent (in terms of consumption equivalents), especially hurting poor households for whom the benefit of increased factor prices does not outweigh the cost of the expenditure and investment channels. We find that using tariff revenue to reduce labor income taxes reduces efficiency, decreasing consumption and output, but in this case, can increase the after-tax wage sufficiently to generate a net gain for poor households. We find that this scenario is very close to being welfare-neutral, leading to an average welfare loss of only 0.02 percent.

Related literature. Our paper is related to several strands of the literature. On the theoretical side, we build on the Ricardian model of trade as in Dornbusch et al. (1977) by introducing Stone-Geary non-homothetic preferences as in Buera and Kaboski (2009), Herrendorf et al. (2013), Uy et al. (2013), and Kehoe et al. (2018) and by introducing households with uninsurable income risk as in Aiyagari (1994), Huggett (1993), and Imrohoroğlu (1989)..$^{3}$

Our paper is also related to recent works that have quantified the heterogeneous welfare gains and losses from trade. Fajgelbaum and Khandelwal (2016) develop an Armington model with non-homothetic preferences and exogenous differences in income to compute the heterogeneous welfare effects of trade along the income distribution. Caliendo et al.

\footnotetext{
${ }^{3}$ See also Matsuyama (2000) who develops a Ricardian model with non-homothetic preferences.
} 
(2018) develop a dynamic trade model with spatially distinct labor markets to quantify the welfare and employment effects of the China trade shock across U.S. labor markets. We complement these papers by focusing on the welfare effects of trade across the income and wealth distribution. Our work is most related to Lyon and Waugh (2019) who also use a Ricardian trade model with uninsurable income risk to study how labor market reallocation frictions affect the gains from trade. We abstract from these frictions and instead focus on the heterogeneous impacts of trade through the expenditure channel.

Our paper is also related to the literature that studies optimal trade and fiscal policies. While Costinot et al. (2015) and Opp (2010) study optimal trade policy in a strategic context, Hosseini and Shourideh (2018) focus on optimal trade and fiscal policy under cooperation. Dixit and Norman (1986) study how gains from trade can be redistributed through taxation. Our work is closely related to Lyon and Waugh (2018) who study how progressive labor income taxation can be used to redistribute the gains from trade. We depart from these papers by focusing on how tariffs interact with labor and capital income taxes. Additionally, there is a large literature examining Ramsey optimal taxation in closed economies with incomplete markets. ${ }^{4}$

On the empirical side, our work is related to two strands of the literature. The first documents the heterogeneity in consumption bundles across income groups, going back to Engel (1857), who documented that food expenditure shares decrease with income (Engel's law) and Houthakker (1957) who documented that Engel's law applies in many countries and for a broad set of goods such as clothing, housing, and other miscellaneous items. More recently, Boppart (2014) documented that poor households spend larger shares of their expenditures on goods. Our contribution to this literature is that we document that Engel's law applies to tradable goods and along the wealth dimension, even after controlling for income and other household characteristics such as age, education, and household size.

Given that households spend varying shares of expenditures on tradable goods, one should expect that trade reforms can have varying impacts on prices that households face. Indeed, another strand of the literature estimates the price effects of trade for different households.

\footnotetext{
${ }^{4}$ See, for example, Aiyagari (1995), İmrohoroğlu (1998), Ventura (1999), Erosa and Gervais (2002), Domeij and Heathcote (2004), Nishiyama and Smetters (2005), Heathcote (2005), Conesa et al. (2009), and Carroll et al. (2016).
} 
Broda and Romalis (2008) and Bai and Stumpner (2018) use scanner data, Jaravel and Sager (2018) use microdata from the Bureau of Labor Statistics, and Amiti et al. (2018) use detailed data on Chinese firms to document the impact of Chinese imports on U.S. prices. Our empirical finding is most related to Broda and Romalis (2008) who document that the price inflation for households in the lowest income decile has been 6 percentage points smaller than inflation for the highest decile between 1994 and 2005, and that one third of the relative price drops faced by the poor are associated with rising Chinese imports. Our findings are in contrast with Borusyak and Jaravel (2018) who also use the Consumer Expenditure Survey to document that import shares are similar across education groups and broadly defined income groups and Hottman and Monarch (2018) who use a structural model and supplier trade data to document that lower income households experienced the most import price inflation. In contrast to these studies, we study expenditures on tradable goods, as opposed to expenditures on imported goods, since changes in trade can have a broad impact on the price of all tradable goods, for example through increased competition and input-output linkages. Furthermore, we find that tradable expenditure shares are decreasing in wealth and income, and that this result is robust to controlling for a variety of household characteristics. More generally, our paper is also related to the recent empirical literature that estimates the heterogeneous impact of trade such as Autor et al. (2013) and Chetverikov et al. (2016).

The remainder of the paper is structured as follows. Section 2 documents the relation between tradable expenditure shares and income and wealth. In section 3, we present a two-country Ricardian model of trade with non-homothetic preferences and heterogeneous agents that face uninsurable labor income risk. In section 4, we discuss the calibration of the model and discuss the main quantitative findings. Section 5 concludes by discussing implications and directions for future research.

\section{Data}

In this section, we use the Panel Survey of Income Dynamics (PSID) and the Consumer Expenditure Survey (CEX) to document the relation between household tradable expenditure shares and labor income and wealth. Our main finding is that tradable expenditure shares 
are decreasing in both labor income and wealth. The differences are both statistically and economically significant.

\subsection{Description of data}

For the PSID, we have 27,918 household-year observations between 2004 and $2014 .^{5}$ Tradable consumption is defined as expenditures on clothing, food at home, prescriptions, home furnishings, and the purchase and lease of cars and trucks. Total consumption is defined as expenditures on child care, clothing, dependents, education, food, health care, housing, transportation, vacation and entertainment, and in the case of home owners, we add owner imputed rent and subtract expenditures on mortgage, property taxes, home insurance, and home repairs. ${ }^{6}$ Labor income is constructed as the sum of household wages and salaries, 50 percent of farm and business income, and unemployment compensation. For wealth, we use a broad measure of net worth, which includes stocks, real estate, noncorporate business assets, bonds, checking and savings accounts, and vehicles, minus debts.

For the CEX, we have 23,748 household-year observations between 2004 and 2014. Tradable consumption is defined as the sum of the 307 items classified as tradable expenditures by the Bureau of Labor Statistics (BLS). Total consumption is defined as the sum of the 568 expenditure items and in the case of home owners, we add the self-reported owner imputed rent and subtract expenditures on mortgage interest, property taxes, home insurance, and home repairs. Labor income is defined as the sum of household wages and salaries, 50 percent of farm and business income, and transfers. For wealth, we use liquid wealth, which is defined as the sum of retirement accounts, checking and savings accounts, and other financial assets. In both data sets, we restrict the sample to households in the labor force and to households with positive amounts of labor income and wealth. ${ }^{7}$

Compared to the PSID, the CEX has the advantage of providing more disaggregated expenditures and self-reported owner imputed rent values. However, the CEX provides a narrower measure of wealth. Thus, we use both data sources to document our findings.

\footnotetext{
${ }^{5}$ The PSID expanded its collection of expenditure data in 2004.

${ }^{6}$ We use information on the price-to-rent ratios at the state level and the self-reported market value of the household's main home to impute the owner imputed rent.

${ }^{7}$ See appendix A for details on how we construct the data sets.
} 
Compared to widely used scanner data, which typically only reports a small fraction of total household expenditures and has only limited information on income and wealth, the PSID and CEX provides information on most household expenditures and detailed information on income, wealth, and other household characteristics.

\subsection{Tradable expenditure, income, and wealth}

Figure 1 plots the relation between tradable expenditure shares and labor income in the (a) PSID and the (b) CEX. While the measured tradable expenditure shares are higher in the CEX than in the PSID, the pattern is the same across both data sets. Households with lower labor income consume a higher share of tradable goods. Moreover, Figure 2 shows that this pattern holds across wealth.

Figure 1: Tradable expenditure shares and labor income

\section{(a) PSID}

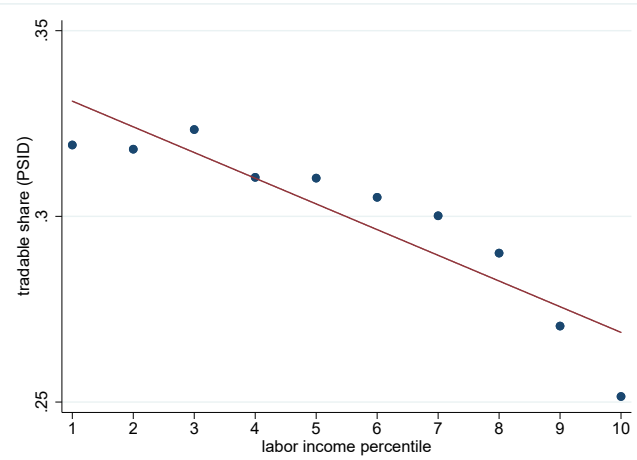

(b) CEX

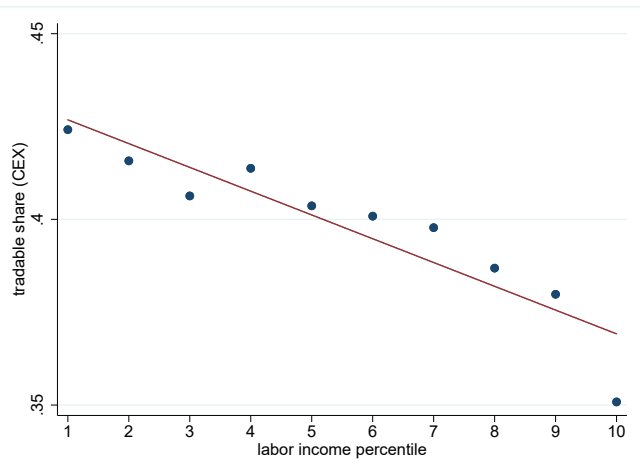

To document the relation in a more systematic way, we regress tradable expenditure shares on the natural logarithm of wealth and income, along with fixed effects for time and household characteristics. Table 1 summarizes our findings using the PSID and the CEX data. The negative relationship between tradable share and income and wealth is robust to controlling for age and education of the household head, household size, and home ownership, with all coefficients significant at the one percent level.

The coefficients are also economically significant. For example, using the coefficients in columns (3) and (6), one standard deviation increases in log wealth are associated with declines in the tradable expenditure share of 1.3 and 0.8 percentage points in the PSID and 
Figure 2: Tradable expenditure shares and wealth

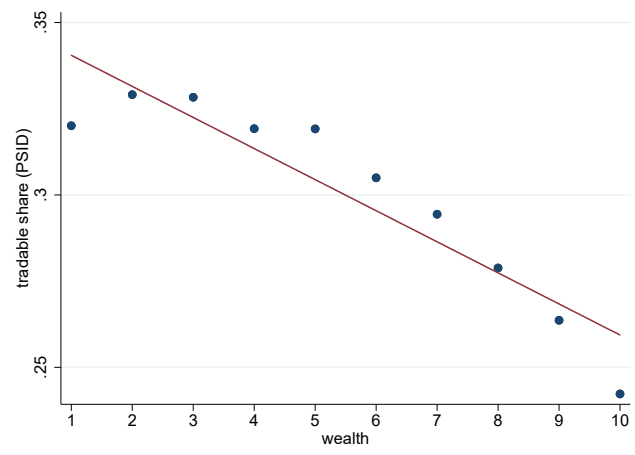

(a) PSID

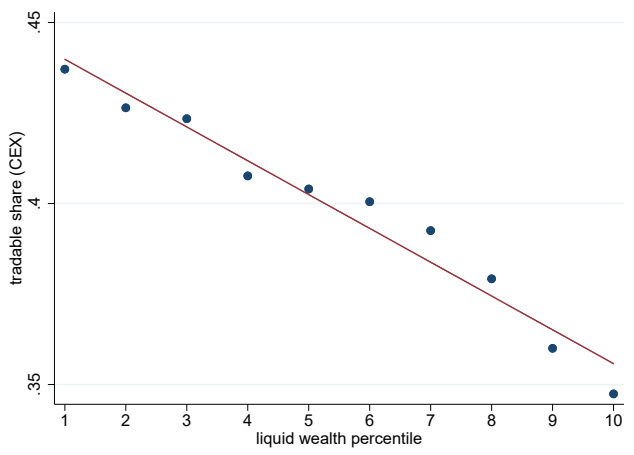

(b) CEX

CEX, respectively. Similarly, one standard deviation increases in log income are associated with declines in the tradable expenditure share of 0.7 and 1.1 percentage points in the PSID and CEX, respectively.

Table 1: Tradable shares, wealth, and income

\begin{tabular}{lcccccc}
\hline \hline & \multicolumn{5}{c}{ Tradable expenditure share (percent) } \\
& PSID & PSID & PSID & CEX & CEX & CEX \\
\hline Wealth & $-1.03^{* * *}$ & $-0.84^{* * *}$ & $-0.64^{* * *}$ & $-1.08^{* * *}$ & $-0.98^{* * *}$ & $-0.33^{* * *}$ \\
& $(0.04)$ & $(0.04)$ & $(0.05)$ & $(0.04)$ & $(0.04)$ & $(0.04)$ \\
& & & & & & \\
Income & & $-0.81^{* * *}$ & $-0.73^{* * *}$ & & $-0.67^{* * *}$ & $-1.13^{* * *}$ \\
& & $(0.09)$ & $(0.09)$ & & $(0.12)$ & $(0.13)$ \\
Household & \multirow{2}{*}{ no } & no & yes & no & no & yes \\
controls & & & & & & \\
\hline Observations & 27692 & 27692 & 27677 & 23648 & 23648 & 23648 \\
Adjusted $R^{2}$ & 0.031 & 0.034 & 0.065 & 0.079 & 0.080 & 0.158 \\
\hline \hline
\end{tabular}

Standard errors in parentheses. All regressions include year fixed effects.

Household control includes age, household size, education, and home owner fixed effects.

${ }^{*} p<0.10,{ }^{* *} p<0.05,{ }^{* * *} p<0.01$

Having established a negative empirical relationship between tradable expenditure share and income or wealth, we next construct a dynamic general equilibrium model with incomplete markets and non-homothetic preferences to measure the quantitative importance of this relationship on welfare. 


\section{Model}

We consider a two-country model with balanced trade without labor or capital flows. There are a continuum of tradable goods indexed by $\omega$ and a single non-tradable numeraire. For convenience we drop time subscripts.

\subsection{Households}

Each country is populated by a mass $L_{i}$ of households who consume a non-tradable good, $c_{N}$, and a consumption bundle made up of tradable goods, $c_{T}$. We assume a separable period utility function

$$
u\left(c_{T}, c_{N}\right)=\frac{\left[c_{T}^{\gamma}\left(c_{N}+\bar{c}\right)^{1-\gamma}\right]^{1-\sigma}}{1-\sigma}-\psi \frac{h^{1+\nu}}{1+\nu}
$$

where $h$ is labor supplied by the household. When $\bar{c}>0$, the utility function represents StoneGeary non-homothetic preferences. Labor is perfectly substitutable across sectors, so there is a single efficiency wage rate, $w_{i}$. Households face uninsurable idiosyncratic productivity risk. Each period, a household draws a realization of labor productivity $\varepsilon$ from a finite set $\mathcal{E}$ and earns a wage $w_{i} \varepsilon$. We assume that $\varepsilon$ follows a Markov process with transition matrix $\Gamma\left(\varepsilon^{\prime}, \varepsilon\right)$. There are no state-contingent claims so households can only self-insure through buying and accumulating capital, $k$. The law of motion for capital follows $k^{\prime}=k(1-\delta)+x$ where $\delta$ is the depreciation rate of capital and $x$ is investment, which is purchased at price $P_{i X}$. A unit of capital has a net return of $r_{i}-\delta P_{i X}$ in the next period. Households pay taxes on labor income and on capital income at rates $\tau_{i \ell}$ and $\tau_{i k}$, respectively. We allow households to claim a depreciation allowance against their capital income. For ease of exposition, define the after-tax wage and the after-tax net return as $\tilde{w}=\left(1-\tau_{i \ell}\right) x$ and $\tilde{r}=\left(1-\tau_{i k}\right)\left(r-\delta P_{i X}\right)$. 


\subsection{Non-tradables producer}

A perfectly competitive representative firm in country $i$ produces non-tradable output $Y_{i N}$ using labor and capital according to

$$
Y_{i N}=z_{i N} L_{i N}^{\alpha_{N}} K_{i N}^{1-\alpha_{N}}
$$

where $z_{i N}$ is a fixed level of productivity. It solves a static profit maximization problem

$$
\begin{aligned}
\max _{L_{i N}, K_{i N}} & P_{i N} Y_{i N}-w_{i} L_{i N}-r_{i} K_{i N} \\
\text { s.t. } & (1)
\end{aligned}
$$

where $\delta$ is the rate of depreciation for capital.

\subsection{Final tradables producer}

A representative final tradables producer in country $i$ bundles the varieties of tradable goods produced in country $o=1,2, q_{o i}(\omega)$, into a single homogeneous consumption good, $Y_{i T}$, according to

$$
Y_{i T}=\left(\int_{0}^{1}\left[\sum_{o=1,2} q_{o i}(\omega)\right]^{\rho} d \omega\right)^{\frac{1}{\rho}}
$$

and sells it to consumers at price, $P_{i T}$. The varieties in the bundle $q_{o i}(\omega)$ are purchased from intermediate tradable producers in country $o$ at price $p_{o}(\omega)$. Given $\left\{p_{o}(\omega)\right\}$ for $o=1,2$ and $\omega \in[0,1]$ and $P_{i T}$, the producer in country $i$ solves

$$
\max _{\left\{q_{o i}(\omega)\right\}_{j=1,2}} P_{i T} Y_{i T}-\int_{0}^{1}\left[\sum_{o=1,2} \tau_{o i} p_{o}(\omega) q_{o i}(\omega)\right] d \omega
$$

s.t. (3) 
where $\tau_{o i}-1$ is a trade cost and satisfies $\tau_{o i}=1$ for $i=o$ and $\tau_{o i} \geq 1$ for $i \neq o$. Note that the producer in country $i$ will purchase a variety $\omega$ from the lowest cost producer. 8 Then, the producer's optimality conditions are given by

$$
q_{o i}(\omega) \leq\left(\frac{\tau_{o i} p_{o}(\omega)}{P_{i T}}\right)^{-\theta} Y_{i T}
$$

which holds with equality if $q_{o i}(\omega)>0$. Furthermore, the tradables price is given by

$$
P_{i T}=\left[\int_{0}^{1} \min _{o}\left\{\tau_{o i} p_{o}(\omega)\right\}^{1-\theta} d \omega\right]^{\frac{1}{1-\theta}}
$$

where $\theta=\frac{1}{1-\rho}$ is the elasticity of substitution across varieties.

\subsection{Intermediate tradables producer}

A representative intermediate tradables firm in country $i$ produces a single variety, $\omega$, of tradable good and hires labor and capital to produce according to the production function

$$
y_{i}(\omega)=z_{i}(\omega) l_{i}(\omega)^{\alpha_{T}} k_{i}(\omega)^{1-\alpha_{T}}
$$

Taking prices $p_{i}(\omega)$ as given, the producer solves

$$
\begin{gathered}
\max _{l_{i}(\omega), k_{i}(\omega)} p_{i}(\omega) y_{i}(\omega)-w_{i} l_{i}(\omega)-r_{i} k_{i}(\omega) \\
\text { s.t. }(7) .
\end{gathered}
$$

The intermediate firm's optimality conditions are given by

$$
\begin{aligned}
& w_{i}=p_{i}(\omega) z_{i}(\omega) \alpha_{T}\left[\frac{k_{i}(\omega)}{l_{i}(\omega)}\right]^{1-\alpha_{T}} \\
& r_{i}=p_{i}(\omega) z_{i}(\omega)\left(1-\alpha_{T}\right)\left[\frac{k_{i}(\omega)}{l_{i}(\omega)}\right]^{-\alpha_{T}} .
\end{aligned}
$$

\footnotetext{
${ }^{8}$ Without loss of generality, we assume that the producer sources domestically in the case that costs are equal.
} 
We assume the productivities for variety $\omega$ in each country is given by

$$
\begin{aligned}
& z_{1}(\omega)=e^{\alpha \omega} \\
& z_{2}(\omega)=e^{\alpha(1-\omega)}
\end{aligned}
$$

so that country $i=1$ (2) has a higher productivity for high (low) $\omega$ varieties.

\subsection{Capital Producer}

The representative capital producer in country $i$ produces investment goods by combining tradable and non-tradable goods according to

$$
X_{i}=z_{i X} I_{i T}^{\eta} I_{i N}^{1-\eta}
$$

Taking prices $P_{i T}, P_{i N}$, and $P_{i X}$ as given, the producer solves

$$
\begin{aligned}
& \max _{I_{T}, I_{N}} P_{i X} X_{i}-P_{i T} I_{i T}-P_{i N} I_{i N} \\
& \text { s.t. }(13) .
\end{aligned}
$$

The capital producer's optimality conditions are given by

$$
\begin{aligned}
& P_{i T}=\eta P_{i X} z_{i X} I_{i T}^{\eta-1} I_{i N}^{1-\eta} \\
& P_{i N}=(1-\eta) P_{i X} z_{i X} I_{i T}^{\eta} I_{i N}^{-\eta}
\end{aligned}
$$

\subsection{Government}

The government in country $i$ finances a constant stream of government expenditure, $G_{i}$, by collecting taxes on labor and capital income and revenue from tariffs. We assume that trade costs, $\tau_{o i}$, are comprised of a technological cost, $\tau_{T, o i} \geq 1$, and a policy cost (i.e., tariff), $\tau_{P, o i} \geq 0$. 


\subsection{Recursive Formulation}

The problem of a household in country $i$ can be stated as

$$
\begin{aligned}
V_{i}(k, \varepsilon)=\max _{c_{T}, c_{N}, h, k^{\prime}} & u\left(c_{T}, c_{N}, h\right)+\beta E_{\varepsilon^{\prime} \mid \varepsilon} V_{i}\left(k^{\prime}, \varepsilon^{\prime}\right) \\
\text { s.t. } & P_{i T} c_{T}+P_{i N} c_{N}+P_{i X}\left(k^{\prime}-k\right) \leq \tilde{w} h \varepsilon+\tilde{r} k \\
& k^{\prime} \geq 0
\end{aligned}
$$

Solving this yields decision rules $g_{i T}(k, \varepsilon), g_{i N}(k, \varepsilon), g_{i h}(k, \varepsilon)$, and $g_{i k}(k, \varepsilon)$ for tradable consumption, non-tradable consumption, labor, and capital, respectively. Define the state space over wealth and labor productivity as $S=K \times E$ and let a $\sigma$-algebra over $S$ be defined by the Borel sets, $\mathcal{B}$, on $S$.

Definition. A steady state recursive equilibrium given fiscal policies $\left\{\tau_{i l}, \tau_{i k}, \tau_{P o i}, G_{i}\right\}_{i=1,2}$ is, for $i=1,2$, a collection of functions $\left\{V_{i}, g_{i T}, g_{i N}, g_{i h}, g_{i k}\right\}$, prices $\left\{r_{i}, w_{i}, P_{i T}, P_{i N}, P_{i X}\right.$, $\left.\left\{p_{i}(\omega)\right\}_{\omega \in[0,1]}\right\}$, non-tradable producer plans $\left\{Y_{i N}, L_{i N}, K_{i N}\right\}$, final tradable producer plans $\left\{Y_{i T},\left\{q_{o i}(\omega)\right\}_{\omega \in[0,1], o=1,2}\right\}$, intermediate tradable producer plans $\left\{y_{i}(\omega), l_{i}(\omega), k_{i}(\omega)\right\}_{\omega \in[0,1]}$, capital producer plans $\left\{X_{i}, I_{i T}, I_{i N}\right\}$, and invariant distributions $\left\{\mu_{i}^{*}\right\}$ such that

1. Given $\left\{r_{i}, w_{i}, P_{i T}, P_{i N} P_{i X}\right\},\left\{V_{i}, g_{i T}, g_{i N}, g_{i h}, g_{i k}\right\}$ satisfy the household problem in (17).

2. Given $\left\{r_{i}, w_{i}, P_{i N}\right\},\left\{Y_{i N}, L_{i N}, K_{i N}\right\}$ solve the problem in (2).

3. Given $\left\{P_{i T},\left\{p_{1}(\omega), p_{2}(\omega)\right\}_{\omega}\right\},\left\{Y_{i T},\left\{q_{i 1}(\omega), q_{i 2}(\omega)\right\}_{\omega}\right\}$ solve the problem in (4).

4. Given $\left\{r_{i}, w_{i}, p_{i}(\omega)\right\},\left\{y_{i}(\omega), l_{i}(\omega), k_{i}(\omega)\right\}$ solve the problem in (8) for $\omega \in[0,1]$.

5. Given $\left\{P_{i T}, P_{i N}, P_{i X}\right\},\left\{X_{i}, I_{i T}, I_{i N}\right\}$ solve the problem in (14).

6. Markets clear:

(a) $Y_{i N}=\int g_{i N}(k, \varepsilon) d \mu_{i}^{*}(k, \varepsilon)+I_{i N},+G_{i}$

(b) $Y_{i T}=\int g_{i T}(k, \varepsilon) d \mu_{i}^{*}(k, \varepsilon)+I_{i T}$,

(c) $X_{i}=\delta \int g_{i k}(k, \varepsilon) d \mu_{i}^{*}(k, \varepsilon)$, 
(d) $y_{i}(\omega)=\tau_{T, i 1} q_{i 1}(\omega)+\tau_{T, i 2} q_{i 2}(\omega)$ for $\omega \in[0,1]$,

(e) $L_{i N}+\int_{0}^{1} l_{i}(\omega) d \omega=L_{i} \int \varepsilon g_{i h}(k, \varepsilon) d \mu_{i}^{*}(k, \varepsilon)$.

7. Trade is balanced: $\int_{0}^{1} \tau_{T, 12} p_{1}(\omega) q_{12}(\omega) d \omega=\int_{0}^{1} \tau_{T, 21} p_{2}(\omega) q_{21}(\omega) d \omega$.

8. Government budget constraint holds, for $o \neq i$ :

$$
\begin{aligned}
G_{i}= & \tau_{i \ell} w_{i} \int_{S} \varepsilon g_{i h}(k, \varepsilon) d \mu_{i}^{*}(k, \varepsilon)+\tau_{i k}\left(r_{i}-\delta P_{i X}\right) \int_{S} k d \mu_{i}^{*}(k, \varepsilon) \\
& +\int_{0}^{1} \tau_{P, o i} p_{o}(\omega) q_{o i}(\omega) d \omega .
\end{aligned}
$$

9. For any subset $(\mathcal{K}, \mathcal{E}) \in \mathcal{B}, \mu_{i}^{*}$ satisfies

$$
\mu_{i}^{*}(\mathcal{K}, \mathcal{E})=\int_{S} \sum_{\varepsilon^{\prime} \in \mathcal{E}} 1_{\left\{g_{i k}(k, \varepsilon) \in \mathcal{K}\right\}} \Gamma\left(\varepsilon^{\prime}, \varepsilon\right) d \mu_{i}^{*}(k, \varepsilon)
$$

\subsection{Characterization of equilibrium}

For simplicity, we assume that the two countries are identical except for the intermediate tradable productivities, which are as specified in equations (11)-(12), so that $w=w_{1}=w_{2}$, $r=r_{1}=r_{2}, \tau=\tau_{12}=\tau_{21}$, et cetera. In what follows, we will omit the country notation unless necessary. We normalize the price of non-tradables, by setting $P_{N}=1$.

By substituting equation (9) in to (10), we obtain the price of variety $\omega$ produced in country $i$,

$$
p_{i}(\omega)=\frac{1}{z_{i}(\omega)}\left(\frac{w}{\alpha_{T}}\right)^{\alpha_{T}}\left(\frac{r}{1-\alpha_{T}}\right)^{1-\alpha_{T}} .
$$

In equilibrium, there are two thresholds which determine the production of the intermediate tradable goods. For $\omega>\bar{\omega}(\tau)$, production takes place only in country $i=1$, where

$$
\bar{\omega}(\tau)=\min \left\{1, \frac{\alpha+\log \tau}{2 \alpha}\right\}
$$

which can be obtained from the condition $\tau p_{2}(\bar{\omega}(\tau))=p_{1} \bar{\omega}(\tau)$. By symmetry, for $\omega<$ $1-\bar{\omega}(\tau)$, production takes place only in country $i=2$. Both countries produce the varieties $\omega \in[1-\bar{\omega}(\tau), \bar{\omega}(\tau)]$. Figure 3 illustrates the pattern of production, trade, and specialization. 
Note that when $\tau=1$, we obtain $\bar{\omega}(\tau)=1 / 2$, which corresponds to free trade and full specialization, and when $\tau>e^{\alpha}$, we obtain $\bar{\omega}(\tau)=1$, which corresponds to autarky.

Figure 3: Pattern of production, trade, and specialization

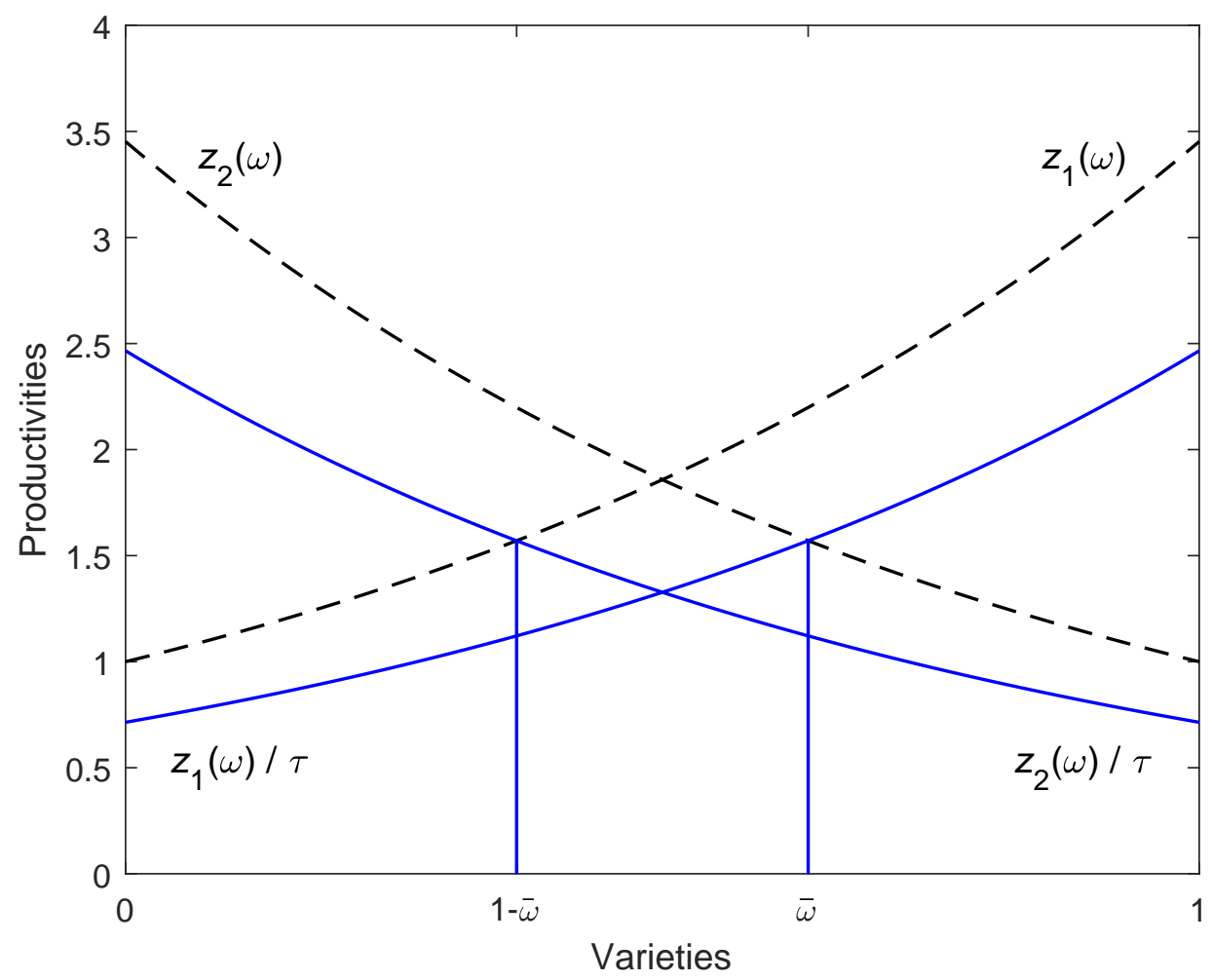

Substituting the price in (18) into the tradable price aggregator in (6), we obtain

$$
P_{T}=\frac{1}{\tilde{z}(\tau)}\left(\frac{w}{\alpha_{T}}\right)^{\alpha_{T}}\left(\frac{r}{1-\alpha_{T}}\right)^{1-\alpha_{T}}
$$

where $\tilde{z}(\tau)$ is a measure of average productivity:

$$
\tilde{z}(\tau)=\left[\tau^{1-\theta} \int_{0}^{1-\bar{\omega}(\tau)} z_{2}(\omega)^{\theta-1} d \omega+\int_{1-\bar{\omega}(\tau)}^{1} z_{1}(\omega)^{\theta-1} d \omega\right]^{\frac{1}{\theta-1}}
$$

Note that $d \tilde{z}(\tau) / d \tau<0$, i.e., lower trade costs result in higher average productivity. Com- 
bining the capital producer's optimality conditions in equations (15) and (16), we obtain

$$
P_{X}=\frac{1}{z_{X}}\left(\frac{P_{T}}{\eta}\right)^{\eta}\left(\frac{1}{1-\eta}\right)^{1-\eta} .
$$

In the special case that $\alpha_{N}=\alpha_{T}$, the tradable price further simplifies to

$$
P_{T}=\frac{z_{N}}{\tilde{z}(\tau)}
$$

In this case, it is straightforward to show that

$$
\frac{d \log \left(P_{T}\right)}{d \tau}=-\frac{d \log (\tilde{z}(\tau))}{d \tau}>0
$$

and

$$
\frac{d \log \left(P_{X}\right)}{d \tau}=-\eta \frac{d \log (\tilde{z}(\tau))}{d \tau}>0
$$

That is, higher trade costs increase the price of tradables by decreasing average productivity in the tradable sector and, to a lesser extent, increase the price of investment. We will quantitatively analyze the effects of a change in trade costs in the next section.

\section{Quantitative Analysis}

\subsection{Calibration}

We choose parameters so that the model's steady-state equilibrium matches several features of the U.S. consumption and wealth distribution. We summarize the parameters in Table 2.

We normalize the labor endowment, $L$, to one. We set the household's discount factor $\beta$, so that the model matches the net-worth-to-GDP ratio in the U.S., 4.8 (2014, U.S. Financial Accounts). We choose the tradable share parameter, $\gamma$, and the non-homothetic preference parameter, $\bar{c}$, so that the model matches the average tradable expenditure shares in the U.S. of 35 percent and that of the top 10 percent of the wealth distribution, 30 percent (2004-2014, PSID and CEX). The household's disutility from labor, $\psi$, is set so that the model generates a share of disposable time spent working, 0.33. We set the labor elasticities in tradables and 
nontradables to 0.67 to match factor shares in both sectors. The parameter that governs the curvature of the productivity distribution, $\alpha$, is set so that the model matches the employment share of the top 17 percent of large U.S. manufacturing establishments (at least 100 employees), 32.1 percent (2014, U.S. Census, Business Dynamics Statistics). We set the tradable share in capital production, $\eta$, to match the tradable share of capital production inputs calculated from the U.S. input-output table, 59 percent (2014, Bureau of Economic Analysis). We assume that the tariff is set to zero, and set the technological trade cost $\tau_{T}-1$ to match the U.S. import share of GDP, 17 percent (2014, World Bank). We assume that the tax rate on labor income, $\tau_{\ell}$, is equal to that on capital income, $\tau_{k}$. The tax rates $\tau_{\ell}=\tau_{k}$ are set so that the model matches the U.S. government consumption share of GDP, 15 percent (2014, OECD).

There are five parameters that we do not calibrate. We set the elasticity of substitution between tradable varieties $\theta$ to be 4 , which is standard in the trade literature and consistent with the estimates by Simonovska and Waugh (2014). We set the household's risk aversion, $\sigma$, to be 2 and the Frisch elasticity, $1 / \nu$, to be 2 , which are standard values in the literature. The labor productivity shocks $\varepsilon$ are assumed to follow an order-one auto-regressive process as follows:

$$
\log \varepsilon_{t}=\rho_{\varepsilon} \log \varepsilon_{t-1}+\nu_{t}, \quad \nu_{t} \sim N\left(0, \sigma_{\nu}^{2}\right)
$$

with persistence $\rho_{\varepsilon}=0.92$ and standard deviation $\sigma_{\nu}=0.21$, following Floden and Lindé (2001). This process is approximated with a seven-state Markov process using the Rouwenhurst procedure described in Kopecky and Suen (2010). Finally, we normalize the productivities in the nontradable and capital sectors, $z_{N}=z_{X}=1$.

\subsection{Quantitative exercise: Increase in tariffs}

In this subsection, we use our calibrated model to analyze the impacts of trade disruptions caused by symmetric increases in tariffs. At the beginning of period one, before any agent's decisions are made, there is an unanticipated increase in $\tau_{P}$ from 0.0 to 0.2 . This is partly motivated by the new tariffs imposed in 2018, which ranged from 10 to 30 percent, on 12 percent of US imports (Congressional Budget Office 2019). 
Table 2: Calibration

\begin{tabular}{lll}
\hline Parameters & Values & Targets / Source \\
\hline \hline Discount factor $\beta$ & 0.96 & Wealth-to-GDP: 4.8 \\
Risk aversion $\sigma$ & 2 & Standard value \\
Tradable share $\gamma$ & 0.65 & Tradable expenditure share: 35 percent \\
Non-homotheticity $\bar{c}$ & 4.77 & Tradable expenditure share of \\
& & wealthiest decile: 30 percent \\
Disutility from labor $\psi$ & 70 & Average hours: 33 percent \\
Frisch elasticity $1 / \nu$ & 2 & Standard value \\
Factor elasticities $\alpha_{T}, \alpha_{N}$ & 0.67 & Labor income share \\
Factor elasticity $\eta$ & 0.59 & Tradable input shares in capital production \\
Elasticity of substitution $\theta$ & 4 & Simonovska and Waugh (2014) \\
Productivity distribution $\alpha$ & 1.24 & Employment share of top 17 percent of large \\
& & manufacturing establishments: 32 percent \\
Trade cost $\tau_{T}-1$ & 0.26 & Import share: 17 percent \\
Income tax $\tau_{\ell}=\tau_{k}$ & 0.18 & Government consumption: 15 percent of GDP \\
Persistence $\rho_{\varepsilon}$ & 0.92 & Floden and Lindé (2001) \\
Standard deviation $\sigma_{\nu}$ & 0.21 & Floden and Lindé (2001) \\
\hline
\end{tabular}

Over time, the two countries transit to the higher cost steady state. Because the wealth distribution evolves over time, prices and household decisions are time-dependent. For clarity, we introduce time subscripts to make explicit that the value function and decision rules depend upon $\mu_{t}(k, \varepsilon)$.

The household problem can be stated recursively as

$$
\begin{aligned}
V_{t}(k, \varepsilon)=\max _{c_{T}, c_{N}, h, k^{\prime}} & u\left(c_{T}, c_{N}, h\right)+\beta E_{\varepsilon^{\prime} \mid \varepsilon} V_{t+1}\left(k^{\prime}, \varepsilon_{t+1}\right) \\
\text { s.t. } & P_{T t} c_{T}+c_{N}+P_{X t}\left(k^{\prime}-k\right) \leq \tilde{w}_{t} h \varepsilon+\tilde{r}_{t} k, \\
& k^{\prime} \geq 0
\end{aligned}
$$

Solving this yields time-dependent decision rules $g_{T t}(k, \varepsilon), g_{N t}(k, \varepsilon), g_{h t}(k, \varepsilon)$, and $g_{k t}(k, \varepsilon)$ for tradables consumption, non-tradables consumption, labor, and saving, respectively.

To solve the transition, we begin with the stationary wealth distribution in the initial steady state, $\mu_{0}^{*}$, at $t=0$. We then introduce a permanent increase in trade costs in 
$t=1$, and solve for a sequence of value functions $\left\{V_{t}\right\}_{t=1}^{\infty}$, decision rules $\left\{g_{T t}, g_{N t}, g_{h t}, g_{k t}\right\}_{t=1}^{\infty}$, wealth distributions $\left\{\mu_{t}\right\}_{t=1}^{\infty}$, and prices $\left\{r_{t}, w_{t}, P_{T t}, P_{X t},\{p(\omega)\}_{\omega}\right\}_{t=1}^{\infty}$, such that given prices, households and firms make optimal decisions, markets clear, and distributions are consistent with household savings decisions.

\subsubsection{Effect on aggregates}

As a baseline case, we study the effects of permanently increasing $\tau_{P}$ by 20 percentage points and using the tariff revenues to finance additional government spending. ${ }^{9}$ In the long run, the increase in total trade costs, $\tau$, from 1.26 to 1.46 , reduces economic activity. The final tradables producer responds to the increase in the cost of foreign varieties by shifting the composition of its inputs toward home produced intermediates ( $\bar{\omega}$ increases). As a result, import share of output falls from 16 percent to 10 percent. As shown in Figure 4(a), the substitution of tradable intermediates from foreign firms to less efficient domestic firms produces an immediate and permanent 3.4 percent increase in the price of tradable goods.

Since capital production uses tradables as an input, some of the rise in the price of tradables passes through to investment prices, as shown in equation (22). $P_{X}$ jumps by 2.0 percent and induces capital-shallowing in the economy. In the long-run, the after-tax wage falls by 1.1 percent, and the after-tax return on capital increases by 2.0 percent. Notice that while the return to capital is higher in the final steady state, it actually falls upon impact after tariffs are imposed and spends a considerable number of periods below its initial steady state level. The initial fall is caused by the change in the investment price which makes purchasing capital more expensive. This feeds into the depreciation cost and reduces the net return on capital. Over time as capital becomes more scarce relative to effective labor, the after-tax return, $\tilde{r}$, rises and eventually more than offsets the change in depreciation cost.

Tariffs reduce real economic activity in the long-run. Figure 5 plots the transition path of the main aggregate variables. In the long-run, real GDP falls by only 0.3 percent, but this value is being propped up by the rise in demand from the government. Due to the increase in tariff revenues, government spending as a percent of GDP is 1.6 percentage points greater

\footnotetext{
${ }^{9}$ This is analogous to the change in iceberg transportation costs typically studied in the trade literature. See, for example, Arkolakis et al. (2012).
} 
Figure 4: Prices

(a) Tradables price

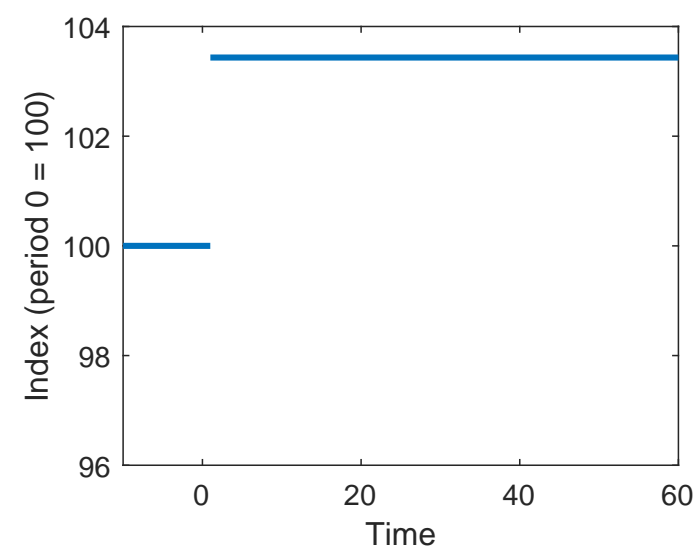

(c) After-tax net return

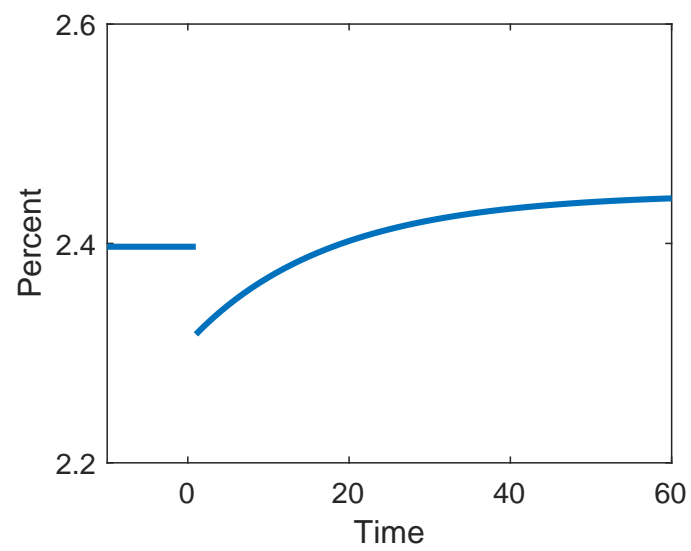

(b) Investment price

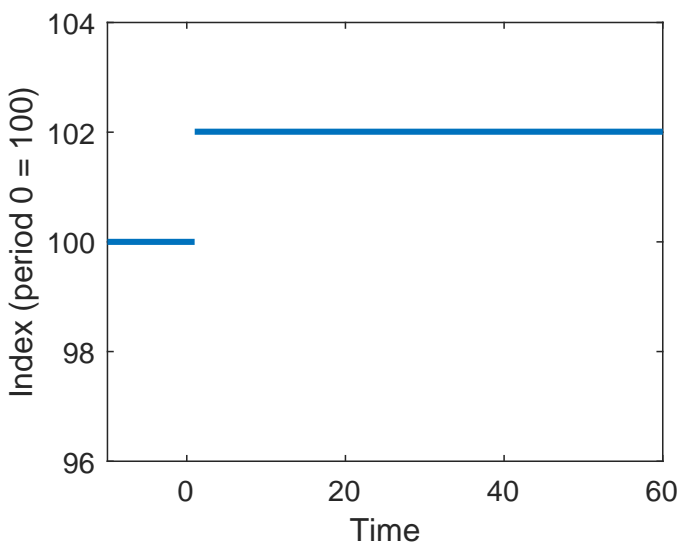

(d) After-tax wage

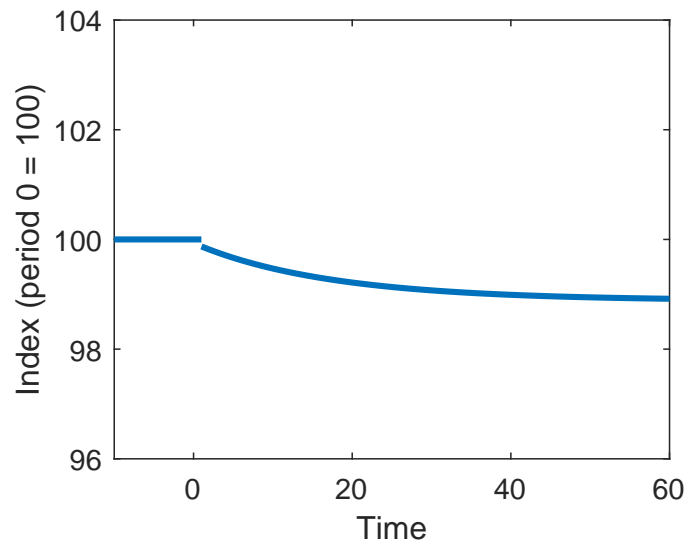


in the final steady state. Meanwhile real household consumption and investment are 2.6 percent and 2.3 percent lower, respectively. The long-run capital stock is 2.3 percent lower, and total hours are slightly higher.

The allocation of factors of production shift across sectors, from tradable to nontradable. Figure 6 plots the transition path of $K_{T}, K_{N}, L_{T}$, and $L_{N}$ after tariffs are imposed. Both capital and labor immediately exit the tradable sector for the nontradable sector. After the initial reallocation, factors in the two sectors follow similar paths as total capital in the economy erodes and aggregate labor input increases.

\subsubsection{Welfare costs}

The dynamics of prices resulting from tariffs leads to differential effects on household welfare across wealth and income. We calculate the distribution of welfare using consumption equivalence. That is, we compute, for each household, by what common percentage, $\Delta$, would initial steady state tradables and nontradables consumption have to be permanently increased in order to make a household indifferent to the policy change. Negative values of $\Delta$ indicate that a household is harmed by raising tariffs since it would be willing to permanently sacrifice consumption to avoid the transition to a higher trade cost environment. Formally, given the household value functions at the beginning of the transition, $V_{1}(k, \varepsilon)$, and the initial steady state decision rules, $g_{k}^{s s}, g_{T}^{s s}$, and $g_{N}^{s s}$, we solve for $\Delta(k, \varepsilon)$, such that

$$
V_{\Delta}(k, \varepsilon)=V_{1}(k, \varepsilon)
$$

where

$$
V_{\Delta}(k, \varepsilon)=u\left((1+\Delta) * g_{T}^{s s},(1+\Delta) * g_{N}^{s s}, g_{h}^{s s}\right)+\beta E_{\varepsilon^{\prime} \mid \varepsilon} V_{\Delta}\left(g_{k}^{s s}, \varepsilon^{\prime}\right)
$$

Figure 7 (a) plots $\Delta$ across the wealth distribution at the moment the policy change is announced for low-productivity and high-productivity households.

First, notice that all households suffer a welfare loss from imposing tariffs. The average welfare loss across all households is 2.8 percent. Second, the welfare losses are not equally distributed, but rather decrease with wealth. A low-wealth household would accept a per- 
Figure 5: Quantities

(a) Consumption

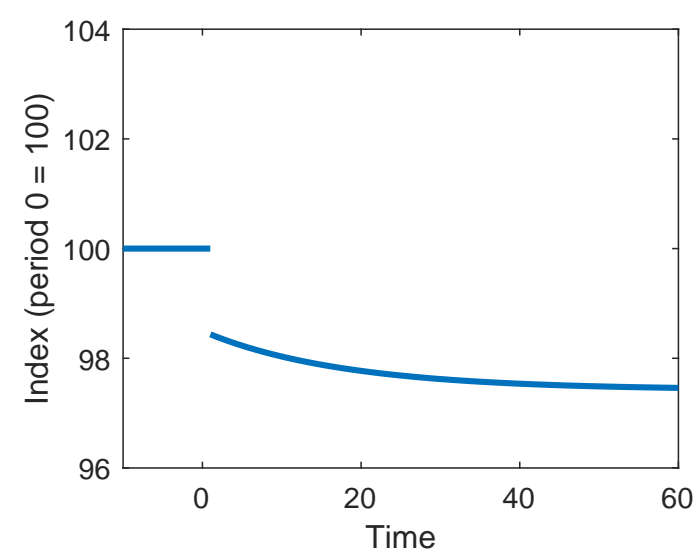

(c) Government expenditure

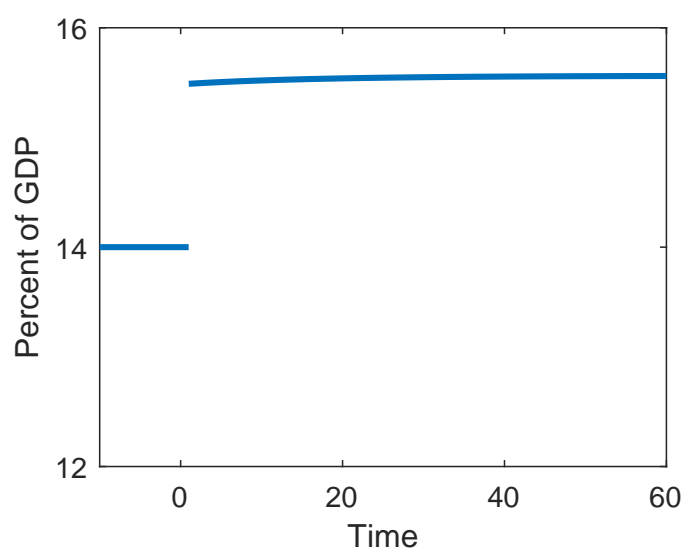

(e) Labor

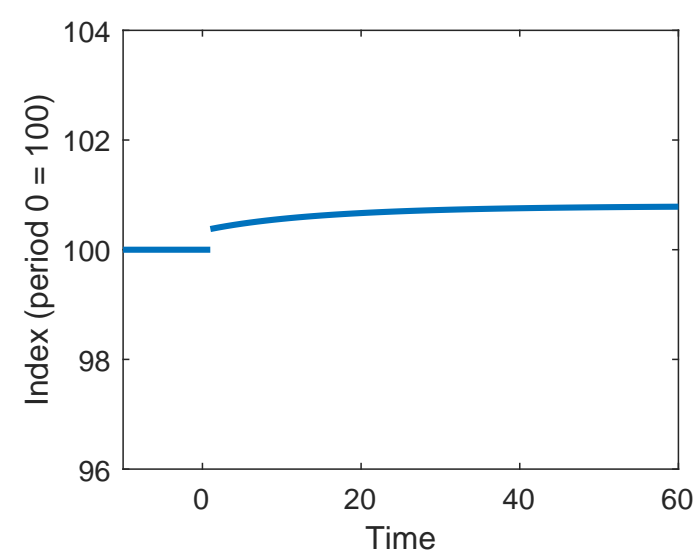

(b) Investment

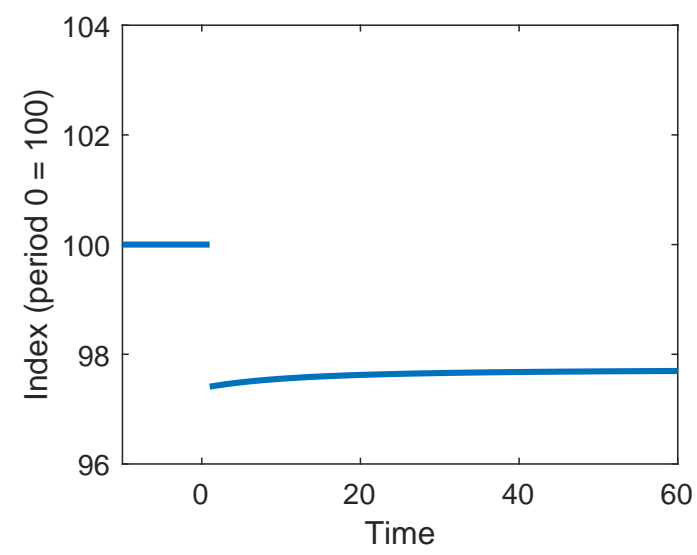

(d) GDP

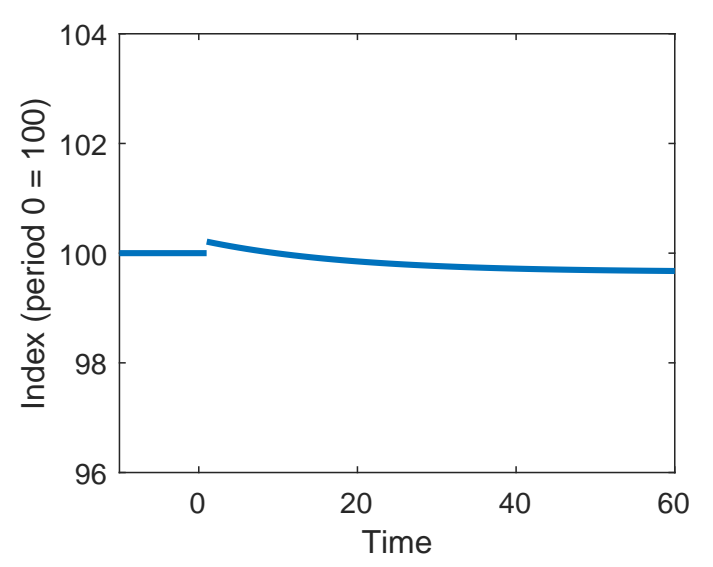

(f) Capital

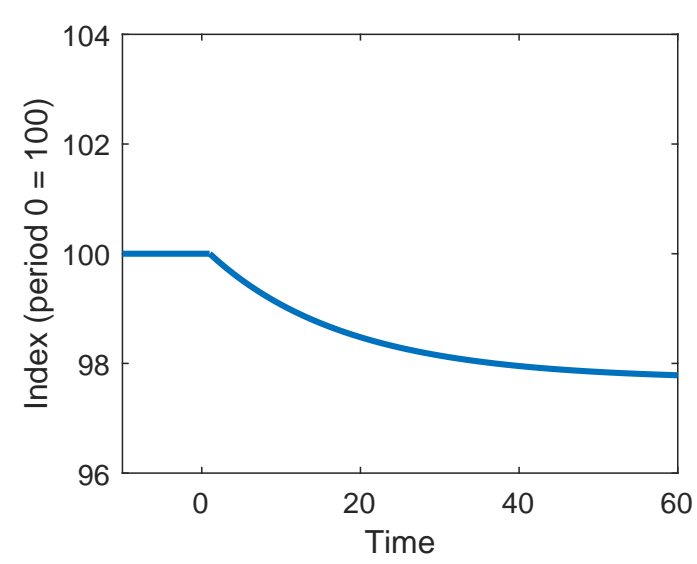


Figure 6: Sectoral reallocation

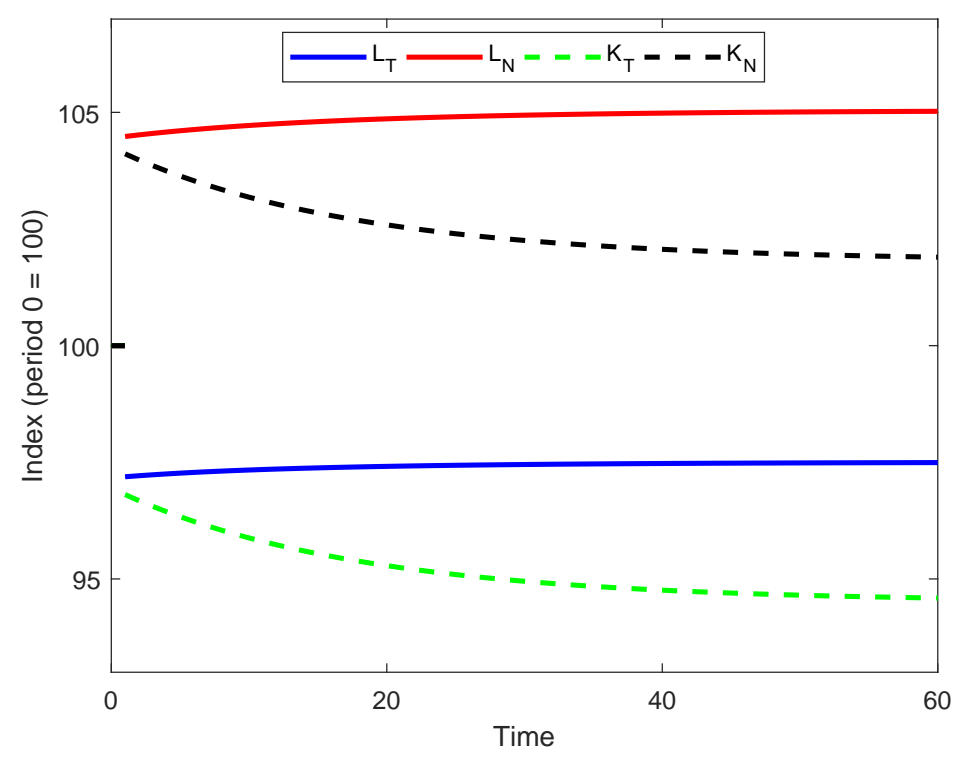

manent decrease in initial steady state consumption of 3.1 percent to forego the change in trade policy, while the average welfare loss for the richest decile of households is only 2.3 percent.

Welfare losses can be attributed to changes in three channels: the expenditure channel, the investment channel, and the factor price channel. Increased trade costs distorts the production of tradables goods, leading to an increase in the tradable price. As a result, poor households, who spend a larger share of expenditures on tradable goods, suffer larger welfare losses - we call this the expenditure channel. Since tradable goods are also an input of capital production, the higher tradable price leads to an increase in the price of investment. This alters the cost of saving, and so it has opposite welfare effects for buyers and sellers of assets. Low-productivity, high-wealth households benefit as they are the ones selling assets in order to smooth consumption, while high-productivity, low-wealth households are worse off as they are buying assets for precautionary savings - this is the investment channel. Finally, the higher investment price leads to capital shallowing, which results in a lower wage and, eventually, a higher return on capital. A change in after-tax returns affects households differently based upon the composition of their income. Because a low-wealth household's total income is derived mostly from labor, it suffers more than a wealthy household does 
Figure 7: Welfare change

(a) Baseline

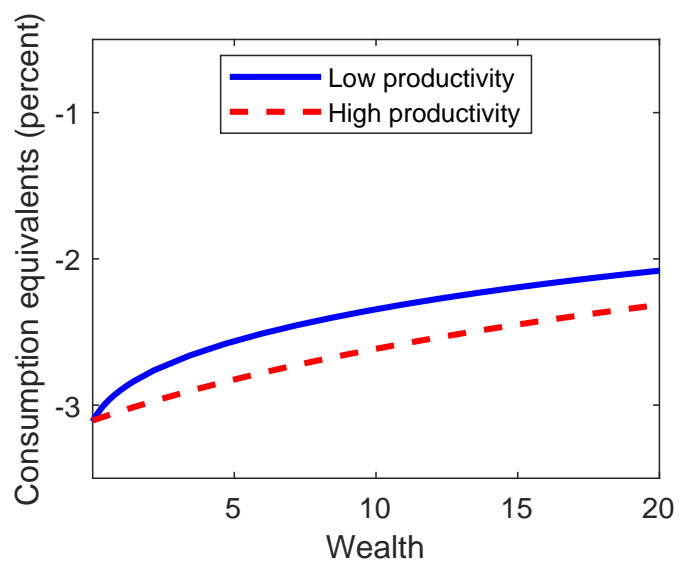

(c) Investment channel

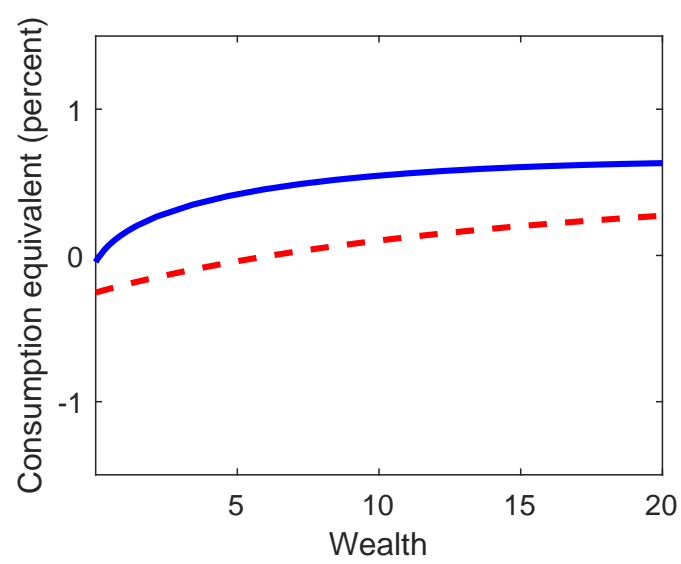

(b) Expenditure channel

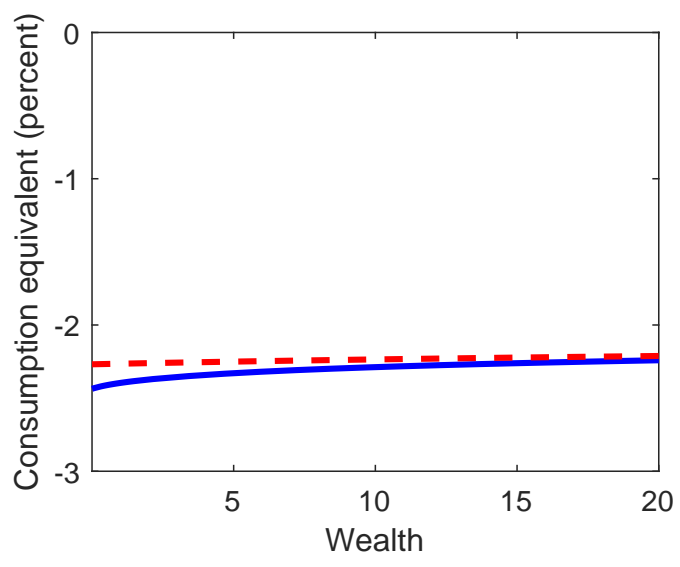

(d) Factor price channel

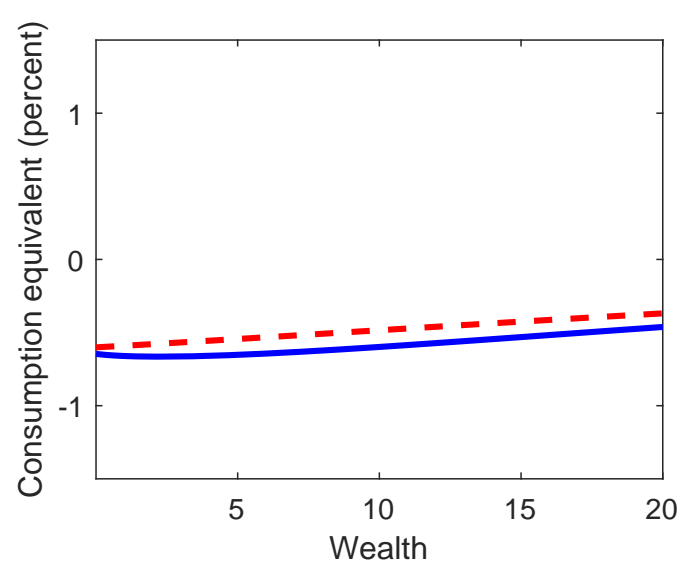


when wages fall, and it benefits less when interest rates rise - this is the factor price channel.

In order to quantify the importance of each of these channels, we conduct a sequence of partial equilibrium exercises. We introduce a measure-zero collection of "ghost" households, who face prices that are different from the equilibrium prices faced by regular households. Ghosts still optimize in response to the prices they face, but because they are zero measure, their decisions have no effect on the equilibrium. We compare three ghost types. The first ghost type only experiences the change in the equilibrium price of tradables. For the second type, only the price of investment is active, and for the final ghost type, only the after-tax wage and return on capital follow their equilibrium paths.

Figure 7(b) plots the consumption equivalents across wealth and income for the first ghost type. In this case, only the tradable price changes. It is evident that the expenditure channel accounts for most of the welfare cost; and it is particularly important for low-wage, low-wealth households.

Figure $7(\mathrm{c})$ plots the distribution of welfare changes for the second ghost type. Here the price of investment jumps to its new equilibrium level while other prices stay fixed. Low productivity households are typically sellers of capital and benefit from the rise in the price of investment. Some low productivity households suffer a small welfare loss resulting from the combination of two factors: first, these households have almost no assets to sell so they benefit little from a rise in the price, and second, they face a positive probability of drawing a higher wage in the future and becoming a buyer again. In expectation, this results in a very small welfare loss. In contrast, high productivity, low wealth households are buyers of capital and thus suffer welfare losses, whereas high productivity, high wealth households gain from a rise in $P_{x}$ through expectations of drawing a lower wage and becoming a seller. On average, the investment channel adds 0.1 percentage points to welfare, but this masks considerable heterogeneity across households. Wealthy, low wage households gain about 0.6 percentage points while poor, high wage households lose almost 0.3 percentage points.

Finally, the welfare costs for the third ghost type are plotted in Figure 7(d). In this case, only $\tilde{r}$ and $\tilde{w}$ change. The factor price channel contributes negatively to total welfare for all households in the range of wealth shown. ${ }^{10}$ The after-tax wage decreases over the transition,

\footnotetext{
${ }^{10}$ This covers approximately 99 percent of all households in the economy.
} 
disproportionately harming the wealth-poor since labor income constitutes a larger portion of their total income. A rise in the after-tax net return on capital would disproportionately benefit wealthy households. However, the equilibrium path of $\tilde{r}$ is complicated by the fact that it initially falls and only gradually rises above its initial steady state value. This greatly mitigates the long-run benefits. As a result, only ghost households with extremely large wealth levels would benefit from the change in $\tilde{r}$, levels far above the maximum held by any households in equilibrium. On average, the factor price channel contributes -0.6 percentage points to the total welfare change.

We find that the welfare change of a regular household in state $(k, \varepsilon)$ is well approximated by the sum of the welfare changes of each ghost type at $(k, \varepsilon)$. Thus, we can use each of these ghost cases as a measure of the approximate contribution to the total welfare loss coming from the three channels. In Table 3, we report the average welfare change for each ghost type for the lowest and highest productivity levels in the bottom and top deciles of the wealth distribution. Among any group, the most important factor for welfare changes is the increase in the price of tradables (expenditure channel).

Table 3: Decomposition of welfare changes (baseline)

\begin{tabular}{lrrrrrr}
\hline \hline & \multicolumn{2}{c}{ Low wealth } & & \multicolumn{2}{c}{ High wealth } & \multirow{2}{*}{ Average } \\
\cline { 2 - 3 } \cline { 5 - 6 } & Low prod. & High prod. & & Low prod. & High prod. & \\
\hline Expenditure channel & -2.44 & -2.27 & & -2.26 & -2.22 & -2.31 \\
Investment channel & -0.04 & -0.25 & & 0.60 & 0.22 & 0.14 \\
Factor price channel & -0.65 & -0.60 & & -0.53 & -0.41 & -0.61 \\
\hline All channels & -3.11 & -3.10 & & -2.20 & -2.41 & $\mathbf{- 2 . 7 7}$ \\
\hline \hline
\end{tabular}

Under the baseline case, where tariffs finance wasteful government spending, the welfare losses from rising trade costs are sizeable for all households, especially for poor households. While the expenditure channel accounts for the largest contribution to welfare losses, movements in factor prices which decrease the after-tax wage permanently and the after-tax return on capital temporarily make up a sizeable cost. Lastly, the investment channel may soften or strengthen the loss from restrictive trade policy depending upon a household's state at the time of the policy change. For low-productivity, wealthy households, the rise in the investment price provides additional consumption at just the right time for low productiv- 
ity households with some capital to sell. Meanwhile, for low wealth households with high productivity, it increases the harm as these are the households for whom the precautionary saving motive is strongest.

\subsection{Alternative fiscal policies}

In the baseline, we concentrated on the distortions arising from a 20 percent tariff and on the distribution of losses across the wealth distribution and abstracted away from potential gains by assuming that tariff revenue is used for wasteful spending. We now relax that assumption. This is important because our environment features a number of distortions arising from incomplete asset markets and binding borrowing limits as well as proportional taxes on labor and on capital income. Given that the agents in our model do not live in a first best world, it is reasonable to ask how the government, using limited fiscal instruments, could mitigate the costs of these distortions. We consider three alternative revenue neutral experiments. In each case, government spending is constant at its initial level over the entire transition. In the first case, the government uses tariff revenue to reduce both labor income and capital income taxes by the same amount. In the next two experiments, the government adjusts either the labor income tax rate or the capital income tax rate to balance its budget.

Notice that these changes in tax policy have no effect on the equilibrium paths of $P_{X}$ or $P_{T}$ since under the case that $\alpha_{T}=\alpha_{N}$ these prices are just functions of total trade costs, as demonstrated in equations (20) and (22). Therefore, the only active channel affecting welfare across the three scenarios is the factor price channel, which the government manipulates by adjusting tax rates.

\subsubsection{Reduction in total income taxes}

First, we clear the government budget constraint with a flat tax on total income. That is, we look for $\left\{\tau_{t}^{\star}\right\}_{t=1}^{T}$, such that the government budget constraint holds in every period, and for every $t=1, \ldots, T, \tau_{\ell, t}=\tau_{k, t}=\tau_{t}^{\star}$. Figure 8 plots the path of the income tax rate following the adoption of tariffs. The increase in tariff revenue facilitates an immediate adjustment of the income tax rate from 18.4 percent to 16.0, as shown in Figure 8. Figure 9 (a) and (b) plots the paths of $\tilde{w}$ and $\tilde{r}$. As in the baseline, imposing tariffs leads to capital shallowing 
in response to higher $P_{X}$, and $\tilde{r}$ has a similar path, dropping initially and then slowly rising to a higher long-run level. In contrast, the effective wage now rises due to the lower income tax rate.

Figure 8: Income tax rates

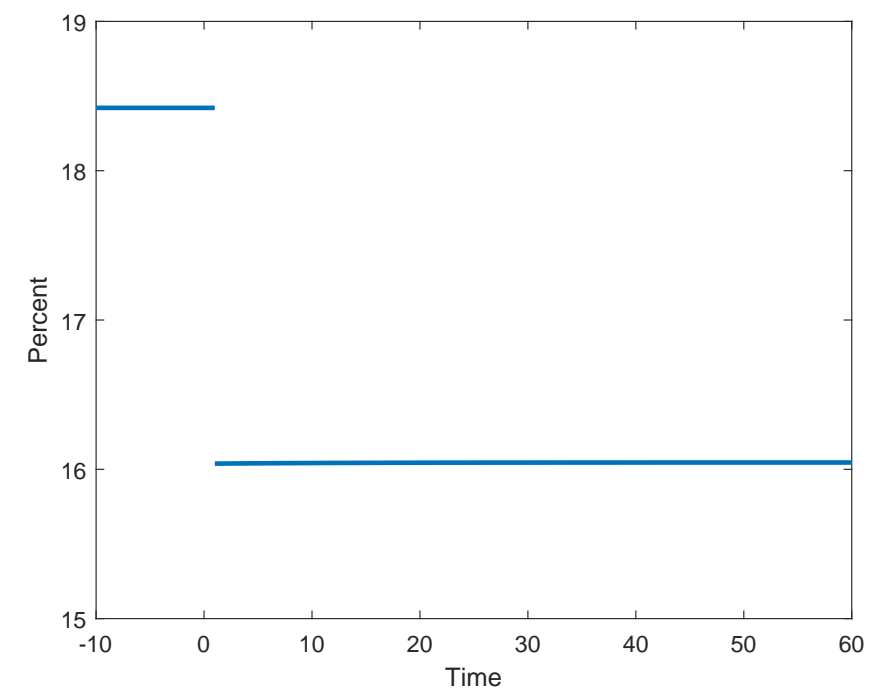

Figure 9: Prices

(a) After-tax net return

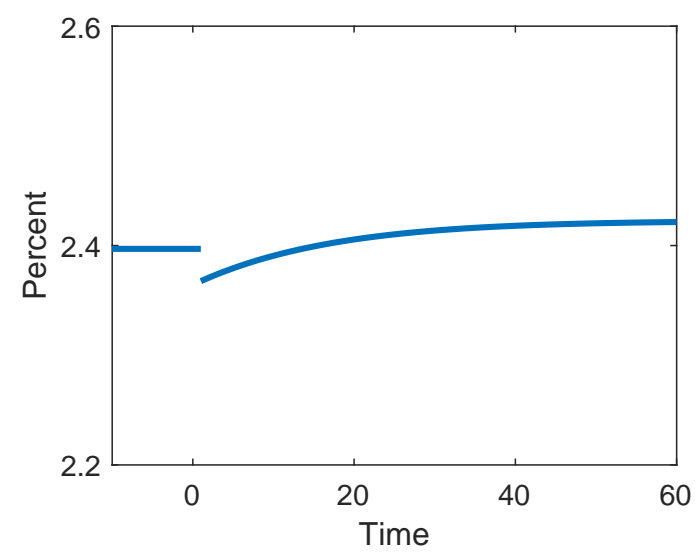

(b) After-tax wage

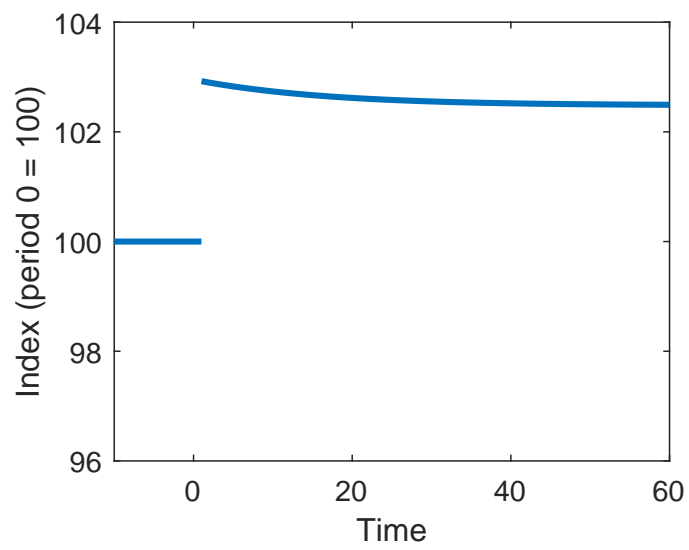

Figure 10 plots the transition path of some of the main aggregate variables. Comparing the new post-tariff steady state to the one in the baseline, GDP falls by the same percentage, but the composition changes greatly. While in the baseline, large declines in the consumption 
and investment were nearly offset by the rise in government spending, here the declines in consumption and investment are much more muted as households have more disposable income. The rise in the after-tax wage also leads to a small increase in aggregate labor.

Figure 10: Quantities

(a) Consumption

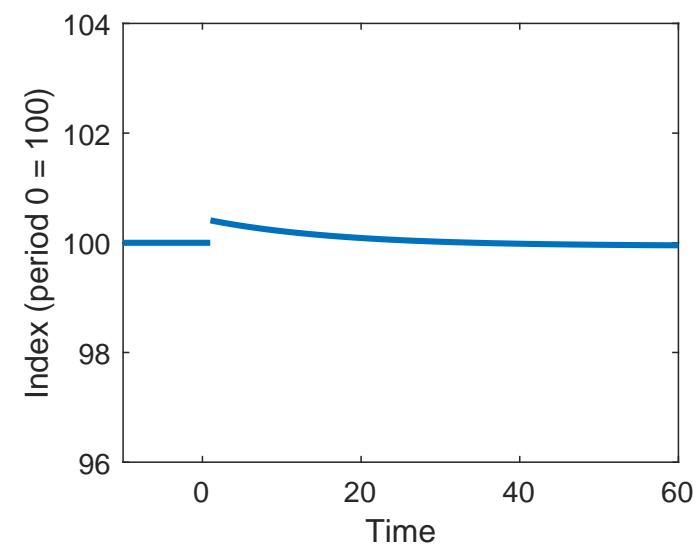

(c) Labor

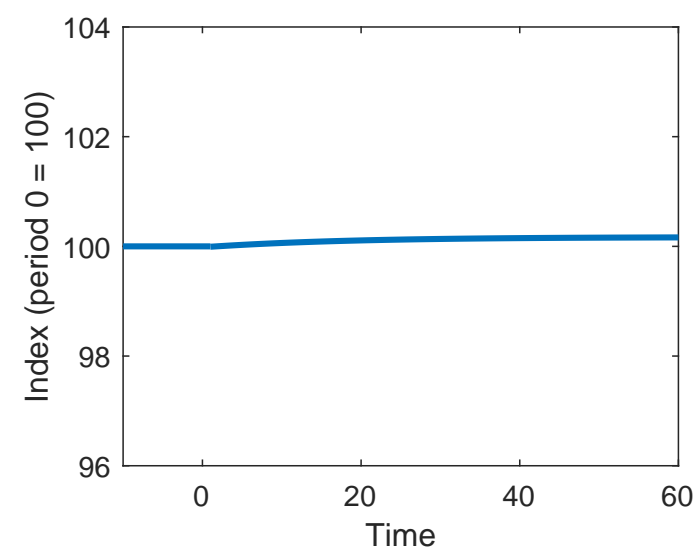

(b) Investment

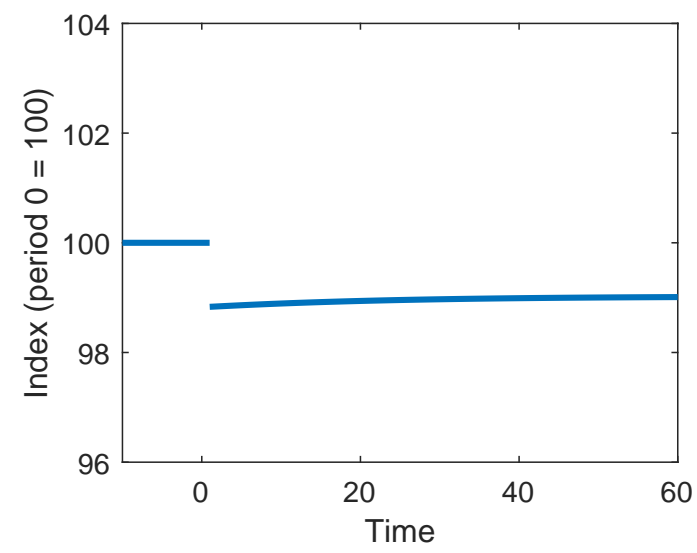

(d) GDP

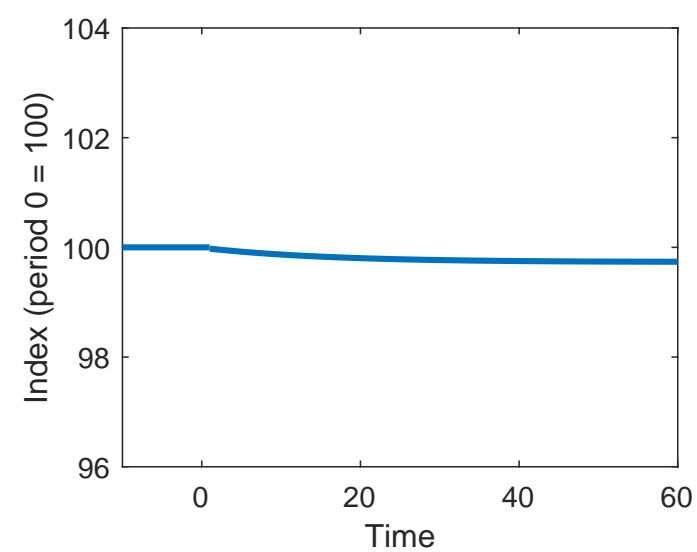

For all households, financing an income tax rate reduction with tariff revenue leads to higher welfare relative to the baseline, nevertheless average welfare is still lower than the no-tariff steady state equilibrium. The average welfare change from imposing tariffs is -0.05 percent. Figure 11(a) plots the welfare changes across the wealth distribution. Low wealth households receive a modest welfare gain from the new trade policy while wealthier households suffer a small loss. The welfare effects from rising tradables and investment prices are 
identical to the baseline, leaving only the after-tax factor price channel to explain the differences in welfare. This is shown in Figure 11(b). Poor households and high-wage households get larger welfare gains from the rise in the effective wage. For the wealth-poor, the gain is especially strong because the extra disposable income eases the cost of being near the borrowing constraint. On net, these gains outweigh the losses from more expensive tradable consumption. Wealthy households still benefit from the movement in the after-tax factor prices, but less than poor households do: first, wealthy households work fewer hours so the rise in after-tax wage, $\tilde{w}$, is less beneficial; second, the after-tax return, $\tilde{r}$, is lower along the early part of the transition; and third, the value of an additional unit of income is much smaller so the tax reduction is less beneficial. For these households the combination of higher tradables prices and higher investment costs dominates.

Figure 11: Welfare change

(a) Baseline

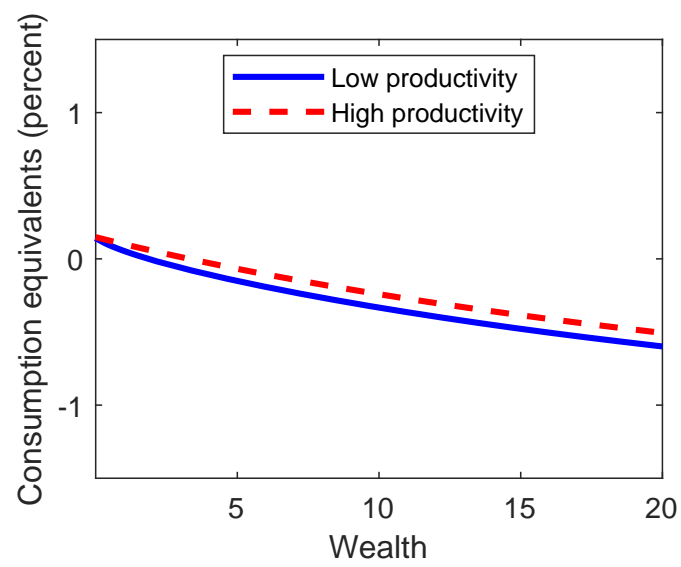

(b) Factor price channel

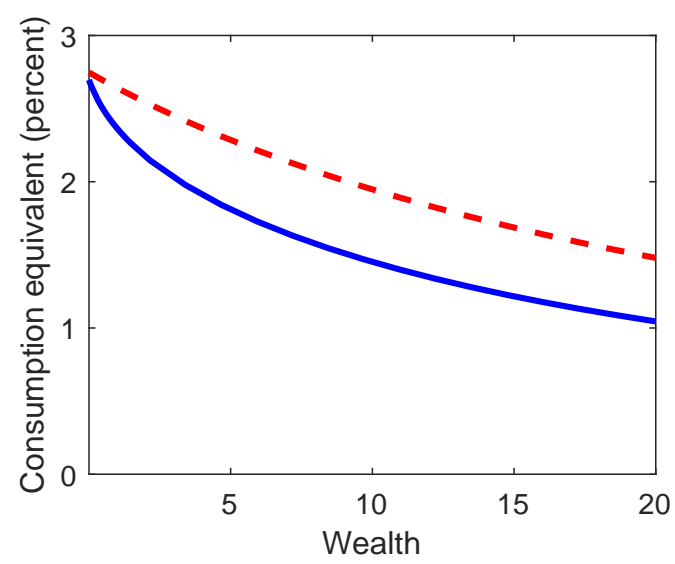

\subsubsection{Reduction in capital income tax rate only}

If the government balances its budget using only $\tau_{k}$, it can almost eliminate capital income taxes completely. The tax rate on capital income falls from 18.4 to less than 2.0 percent (Figure 12), and the effective return on capital jumps up, as shown in Figure 13(a). This boosts investment, leading to capital deepening. The effective wage declines slightly following the change in the trade policy as household labor supply increases initially, but as capital accumulates, it rapidly becomes more abundant to labor, and soon the wage recovers and 
settles above its initial level. As shown in Figure 14, capital deepening leads to an increase in real GDP along the transition. However, most of the increase in GDP goes to maintaining a higher level of aggregate capital; household aggregate consumption rises by only 0.5 percent.

Figure 12: Tax rates

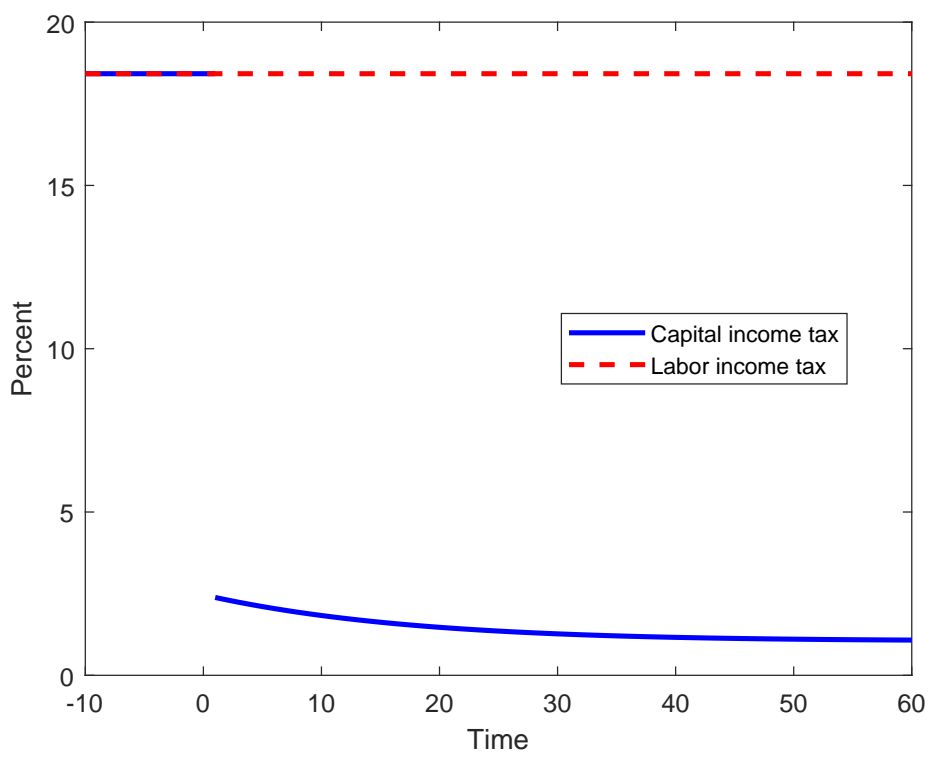

Figure 13: Prices

(a) After-tax net return

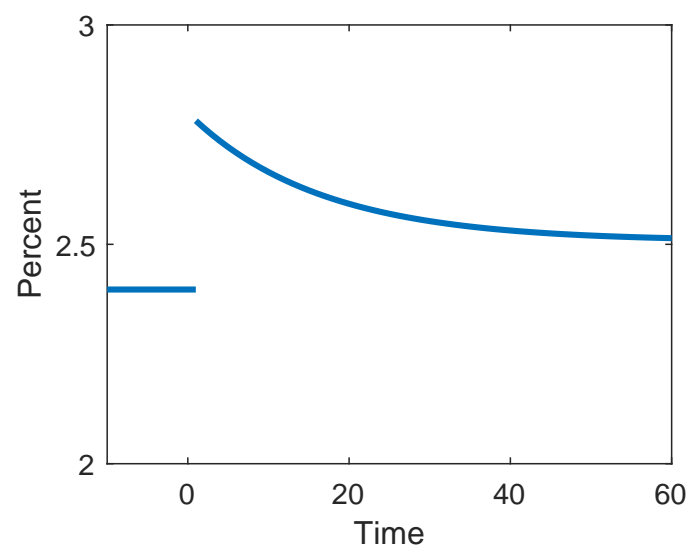

(b) After-tax wage

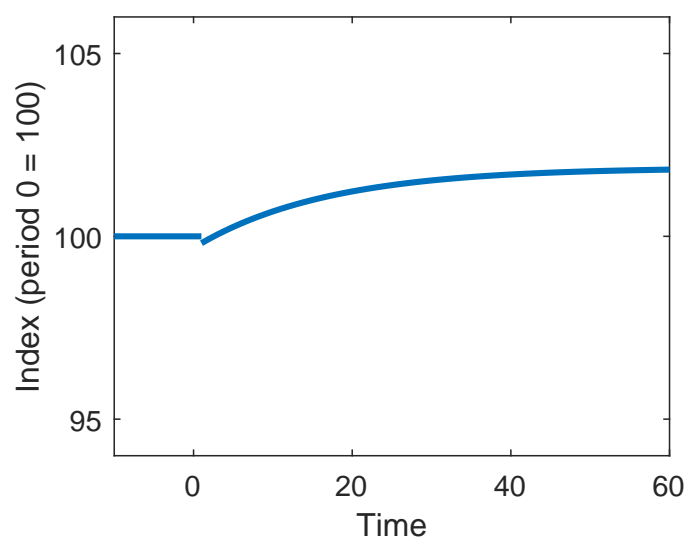

Imposing tariffs and reducing capital income taxes leads to an average welfare loss of 0.25 percent. It is evident from Figure 15 that this is due to large welfare losses among the poor. While these households benefit from the change in after-tax wages and returns, they do not 
Figure 14: Quantities

(a) Consumption

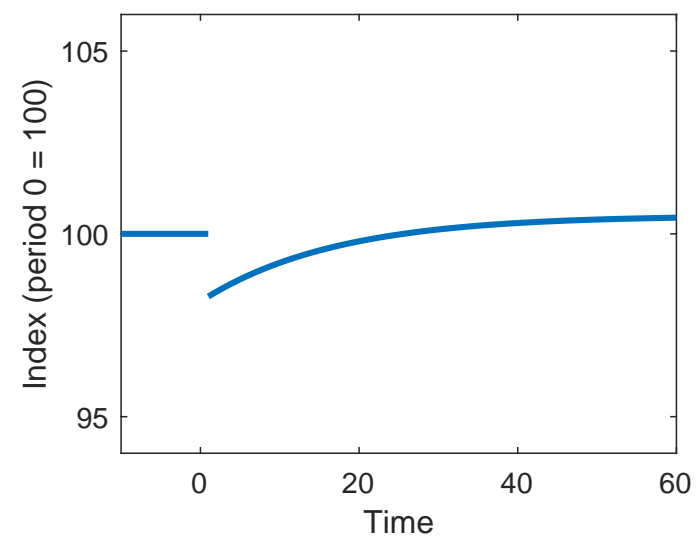

(c) Labor

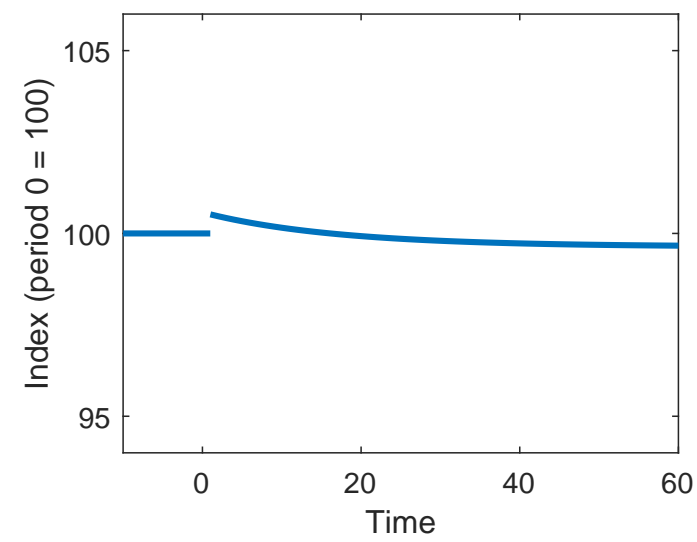

(b) Investment

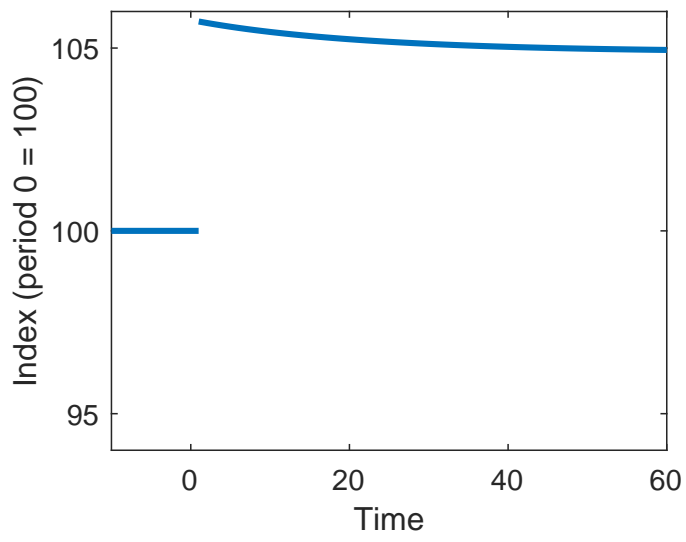

(d) GDP

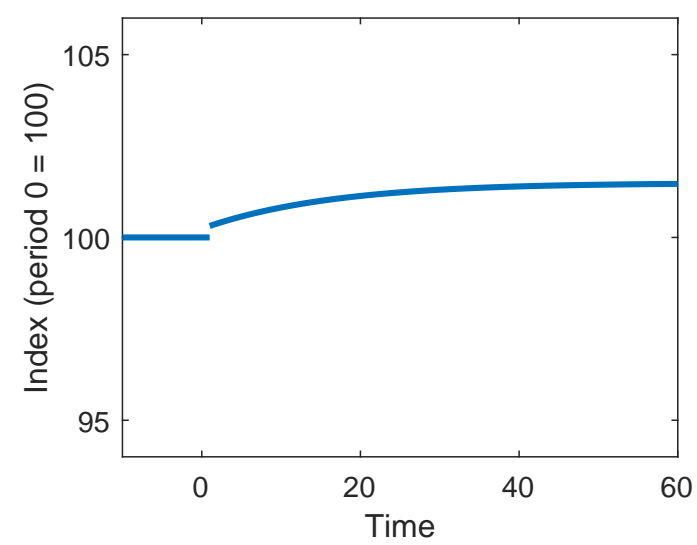


have enough wealth to achieve the very large gains that rich households enjoy, and so they cannot fully offset the welfare losses coming the from the increase in tradables prices. In contrast, the wealthy on net receive big welfare gains from this policy, particularly those with low wages because they sell capital at a higher $P_{X}$ than before. Despite these large gains, there are relatively few rich households so they have a small effect on average welfare.

Figure 15: Welfare change

(a) Baseline

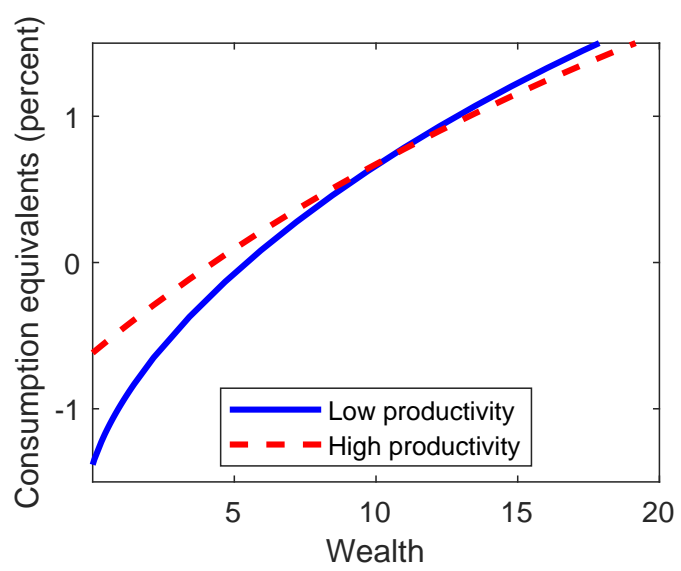

(b) Factor price channel

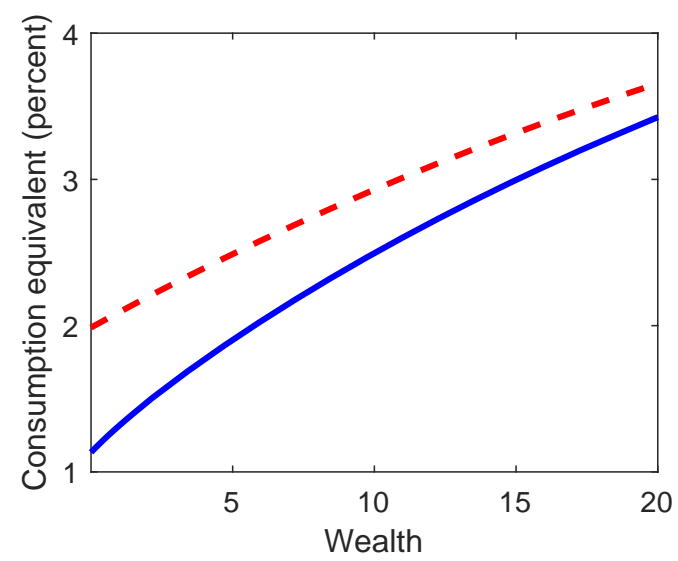

\subsubsection{Reduction in labor income taxes only}

Lastly, we let the government offset tariff revenues with a lower labor income tax. Following the change in trade policy, the labor income tax falls by 2.8 percentage points (Figure 16). Immediately after tariffs are imposed, the after-tax wage jumps up and then declines over time to a new, higher steady state level. The after-tax return on capital drops immediately due to the rise in depreciation cost before climbing back to near its original level (Figure 17). As investment falls (Figure 18), real GDP and consumption fall by 0.6 and 0.2 percent, respectively.

Of all the fiscal policies considered, reducing the labor income tax rate produces the smallest average welfare loss, only 0.02 percent. Figure 19 shows that this policy achieves a lower welfare cost for the same reason that capital income tax rate reductions did not: it allocates welfare gains away from the rich and toward the poor, which makes up a greater fraction of the population. The poor earn most of their income through labor so they benefit 
Figure 16: Tax rates

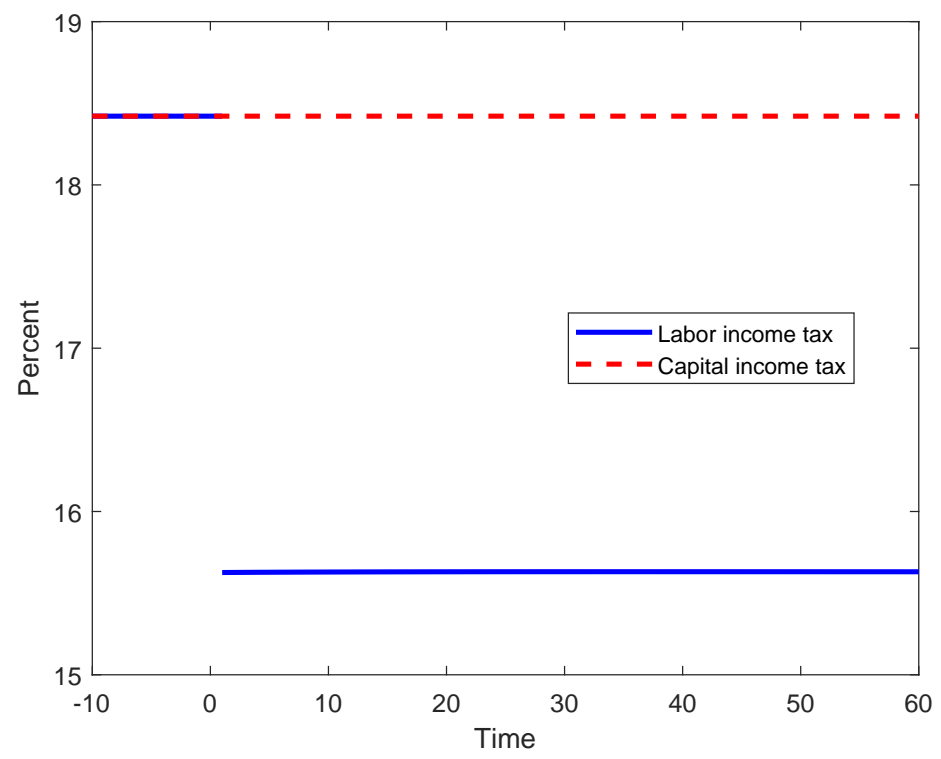

Figure 17: Prices

(a) After-tax net return

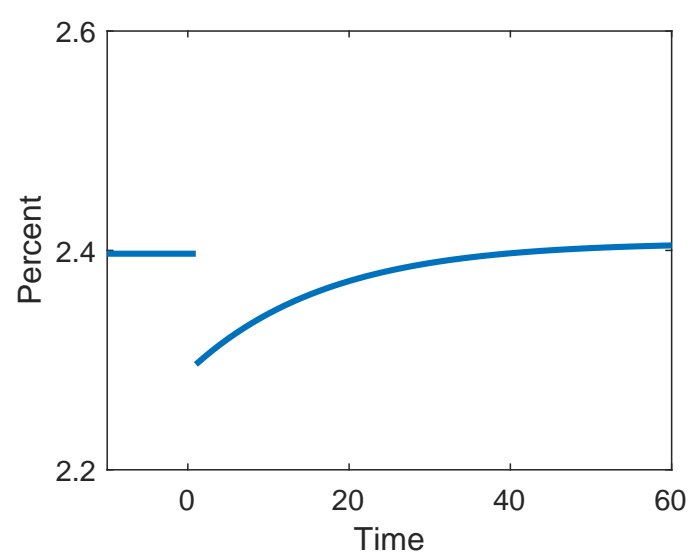

(b) After-tax wage

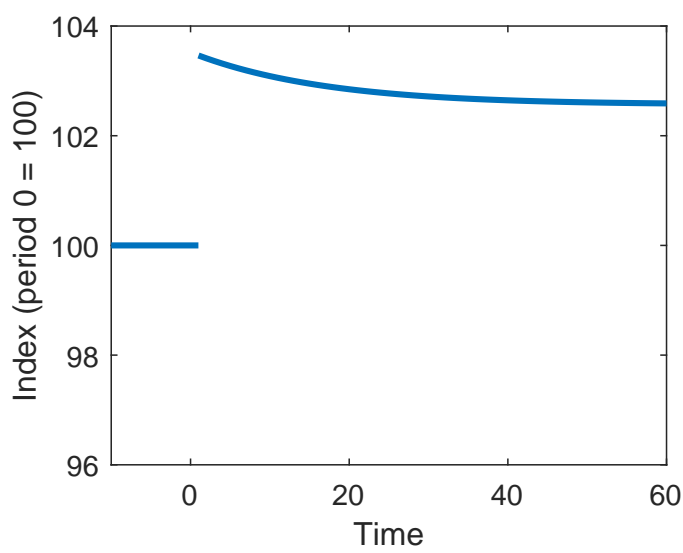


Figure 18: Quantities

(a) Consumption

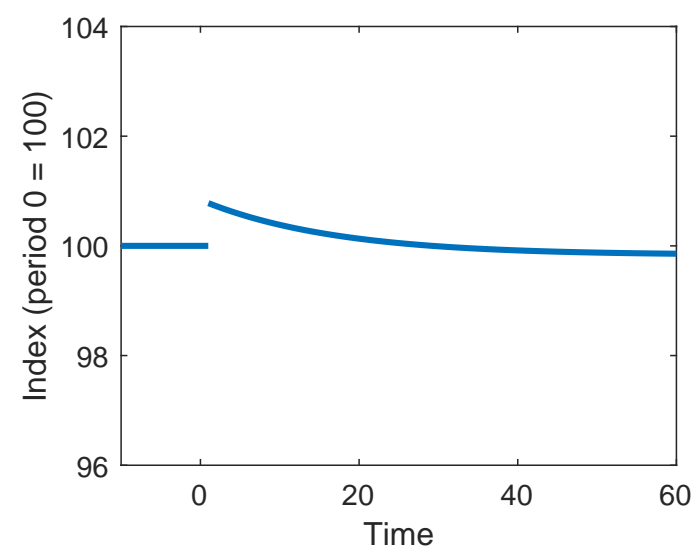

(c) Labor

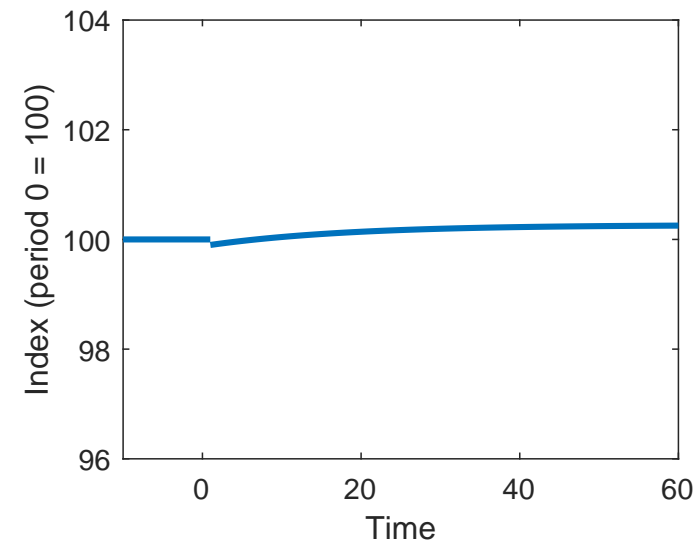

(b) Investment

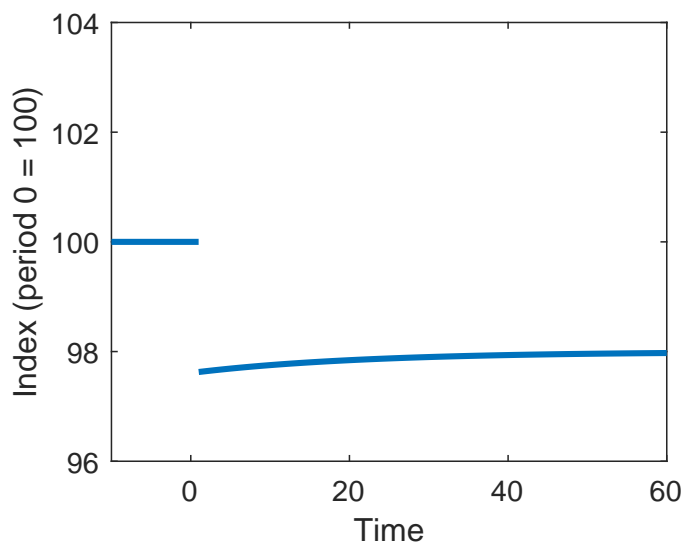

(d) GDP

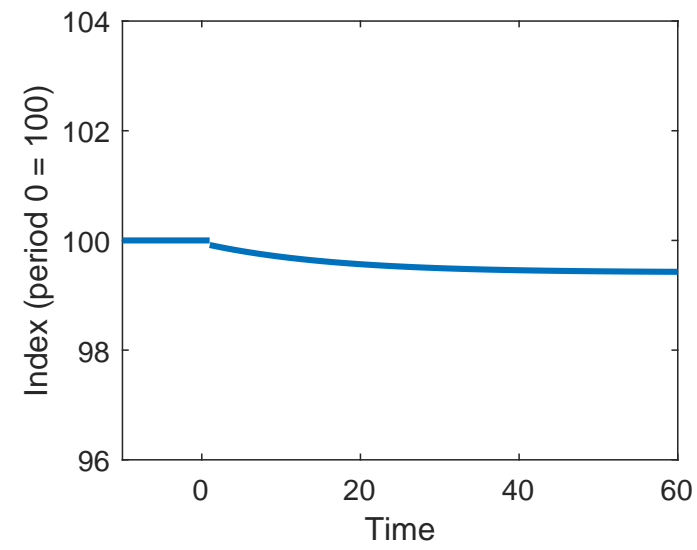


greatly when their after-tax wage increases. Table 4 summarizes our findings for welfare across the three fiscal policy experiments.

Figure 19: Welfare change

(a) Baseline

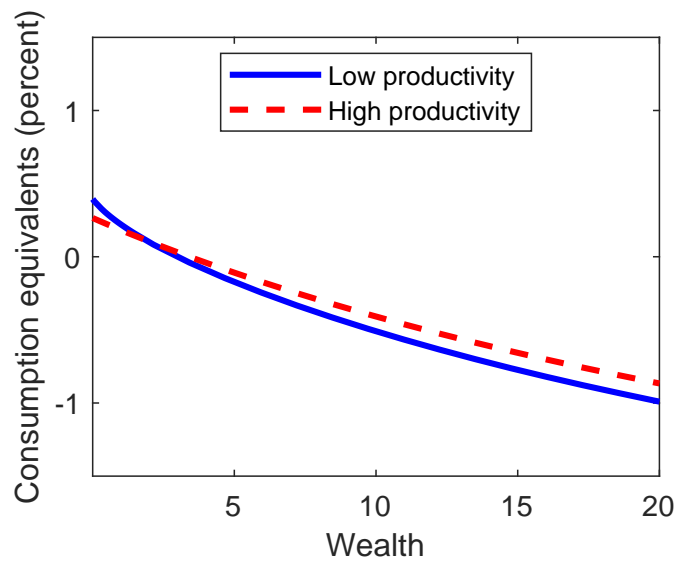

(b) Factor price channel

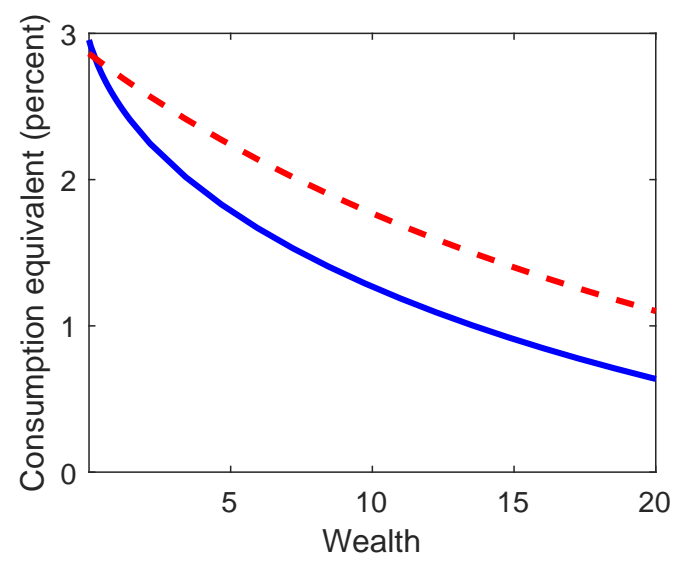

Table 4: Decomposition of welfare changes (alternative fiscal policies)

\begin{tabular}{lrrrrrr}
\hline \hline & \multicolumn{2}{c}{ Low wealth } & & \multicolumn{2}{c}{ High wealth } & \multirow{2}{*}{ Average } \\
\cline { 2 - 3 } \cline { 5 - 6 } & Low prod. & High prod. & & Low prod. & High prod. & \\
\hline Expenditure channel & -2.44 & -2.27 & & -2.26 & -2.22 & -2.30 \\
Investment channel & -0.04 & -0.25 & & 0.60 & 0.22 & 0.14 \\
Factor price channel & & & & & & \\
$\quad$ Total income tax & 2.69 & 2.74 & & 1.23 & 1.63 & 2.18 \\
Capital income tax & 1.14 & 1.99 & & 2.97 & 3.41 & 1.99 \\
Labor income tax & 2.95 & 2.85 & & 0.93 & 1.32 & 2.20 \\
\hline All channels & & & & & \\
Total income tax & 0.14 & 0.15 & & -0.47 & -0.42 & $\mathbf{- 0 . 0 5}$ \\
Capital income tax & -1.38 & -0.61 & & 1.19 & 1.26 & $\mathbf{- 0 . 2 5}$ \\
Labor income tax & 0.39 & 0.26 & & -0.75 & -0.71 & $\mathbf{- 0 . 0 2}$ \\
\hline \hline
\end{tabular}

Units: percent.

\section{Conclusion}

We have documented that the share of household consumption expenditure on tradable goods is a decreasing function of household income and wealth. This implies that low-income and 
financially constrained households could be more exposed to disruptions in trade which affect the price of tradable consumption goods. We calibrate a two-country dynamic stochastic general equilibrium model with incomplete markets and non-homothetic preferences and use it to measure the welfare consequences of moving to a high trade cost policy. In the absence of redistribution through taxes, poor households suffer larger welfare losses than the rich. While the primary reason is a rise in the price of tradable consumption, changes in after-tax wages and returns to capital exacerbate the welfare consequences. A rise in investment costs induced by higher tariffs is an important factor for poor households with high wages as it makes accumulating capital more expensive. If the government uses tariff revenue to offset other distortionary taxes in the economy, average welfare costs are lowest when it targets poor households by reducing labor income taxes. Our results suggest that increasing the progressivity of labor income taxation would reduce average welfare costs further, perhaps even leading to a welfare gain (see, for example, Lyon and Waugh 2018). We leave this potential extension and the study of optimal trade and fiscal policies in a richer framework for future research. 


\section{References}

Aiyagari, S Rao, "Uninsured idiosyncratic risk and aggregate saving," The Quarterly Journal of Economics, 1994, 109 (3), 659-684.

Aiyagari, S Rao, "Optimal capital income taxation with incomplete markets, borrowing constraints, and constant discounting," Journal of political Economy, 1995, 103 (6), 11581175.

Amiti, Mary, Mi Dai, Robert Feenstra, and John Romalis, "How Did China's WTO Entry Affect US Prices?," 2018.

Arkolakis, Costas, Arnaud Costinot, and Andrés Rodríguez-Clare, "New trade models, same old gains?," American Economic Review, 2012, 102 (1), 94-130.

Autor, David H, David Dorn, and Gordon H Hanson, "The China syndrome: Local labor market effects of import competition in the United States," American Economic Review, 2013, 103 (6), 2121-68.

Bai, Liang and Sebastian Stumpner, "Estimating US Consumer Gains from Chinese Imports," American Economic Review: Insights, 2018.

Boppart, Timo, "Structural change and the Kaldor facts in a growth model with relative price effects and non-Gorman preferences," Econometrica, 2014, 82 (6), 2167-2196.

Borusyak, Kirill and Xavier Jaravel, "The Distributional Effects of Trade: Theory and Evidence from the United States," 2018.

Broda, Christian and John Romalis, "Inequality and prices: does China benefit the poor in America?," Unpublished 2008.

Buera, Francisco J and Joseph P Kaboski, "Can traditional theories of structural change fit the data?," Journal of the European Economic Association, 2009, 7 (2-3), 469477. 
Caliendo, Lorenzo, Maximiliano A Dvorkin, and Fernando Parro, "Trade and Labor Market Dynamics: General Equilibrium Analysis of the China Trade Shock," Econometrica, 2018.

Carroll, Daniel R, Jim Dolmas, and Eric R Young, "The politics of flat taxes," Technical Report, Technical report 2016.

Chetverikov, Denis, Bradley Larsen, and Christopher Palmer, "IV quantile regression for group-level treatments, with an application to the distributional effects of trade," Econometrica, 2016, 84 (2), 809-833.

Conesa, Juan Carlos, Sagiri Kitao, and Dirk Krueger, "Taxing capital? Not a bad idea after all!," American Economic Review, 2009, 99 (1), 25-48.

Congressional Budget Office, "The Budget and Economic Outlook: 2019 to 2029," 2019.

Costinot, Arnaud, Dave Donaldson, Jonathan Vogel, and Iván Werning, "Comparative advantage and optimal trade policy," The Quarterly Journal of Economics, 2015, $130(2), 659-702$.

Dixit, Avinash and Victor Norman, "Gains from trade without lump-sum compensation," Journal of International Economics, 1986, 21 (1-2), 111-122.

Domeij, David and Jonathan Heathcote, "On the distributional effects of reducing capital taxes," International economic review, 2004, 45 (2), 523-554.

Dornbusch, Rudiger, Stanley Fischer, and Paul Anthony Samuelson, "Comparative advantage, trade, and payments in a Ricardian model with a continuum of goods," The American Economic Review, 1977, 67 (5), 823-839.

Engel, Ernst, "Die produktions-und konsumptionsverhältnisse des königreichs sachsen," Zeitschrift des Statistischen Bureaus des Königlich Sächsischen Ministeriums des Innern, $1857,8,1-54$.

Erosa, Andres and Martin Gervais, "Optimal taxation in life-cycle economies," Journal of Economic Theory, 2002, 105 (2), 338-369. 
Fajgelbaum, Pablo D and Amit K Khandelwal, "Measuring the unequal gains from trade," Quarterly Journal of Economics, 2016, 131 (3), 1113-1180.

Floden, Martin and Jesper Lindé, "Idiosyncratic risk in the United States and Sweden: Is there a role for government insurance?," Review of Economic dynamics, 2001, 4 (2), 406-437.

Galle, Simon, Andres Rodriguez-Clare, and Moises Yi, "Slicing the pie: Quantifying the aggregate and distributional effects of trade," Technical Report, National Bureau of Economic Research 2017.

Heathcote, Jonathan, "Fiscal policy with heterogeneous agents and incomplete markets," The Review of Economic Studies, 2005, 72 (1), 161-188.

Herrendorf, Berthold, Richard Rogerson, and Akos Valentinyi, "Two perspectives on preferences and structural transformation," American Economic Review, 2013, 103 (7), 2752-89.

Hosseini, Roozbeh and Ali Shourideh, "Inequality, Redistribution and Optimal Trade Policy: A Public Finance Approach," Available at SSRN 3159475, 2018.

Hottman, Colin and Ryan Monarch, "Estimating Unequal Gains across US Consumers with Supplier Trade Data," 2018.

Houthakker, Hendrik Samuel, "An international comparison of household expenditure patterns, commemorating the centenary of Engel's law," Econometrica, Journal of the Econometric Society, 1957, pp. 532-551.

Huggett, Mark, "The risk-free rate in heterogeneous-agent incomplete-insurance economies," Journal of economic Dynamics and Control, 1993, 17 (5-6), 953-969.

Imrohoroğlu, Ayşe, "Cost of business cycles with indivisibilities and liquidity constraints," Journal of Political economy, 1989, 97 (6), 1364-1383.

İmrohoroğlu, Selahattin, "A quantitative analysis of capital income taxation," International Economic Review, 1998, pp. 307-328. 
Jaravel, Xavier and Erick Sager, "What Are the Price Effects of Trade? Evidence From the US and Implications for Quantitative Trade Models," Unpublished 2018.

Kehoe, Timothy J, Kim J Ruhl, and Joseph B Steinberg, "Global imbalances and structural change in the United States," Journal of Political Economy, 2018, 126 (2), $761-796$.

Kopecky, Karen A and Richard MH Suen, "Finite state Markov-chain approximations to highly persistent processes," Review of Economic Dynamics, 2010, 13 (3), 701-714.

Lyon, Spencer and M Waugh, "Quantifying the Losses from International Trade," Unpublished 2019.

Lyon, Spencer G and Michael E Waugh, "Redistributing the gains from trade through progressive taxation," Journal of International Economics, 2018, 115, 185-202.

Matsuyama, Kiminori, "A ricardian model with a continuum of goods under nonhomothetic preferences: Demand complementarities, income distribution, and north-south trade," Journal of political Economy, 2000, 108 (6), 1093-1120.

Nishiyama, Shinichi and Kent Smetters, "Consumption taxes and economic efficiency with idiosyncratic wage shocks," Journal of political Economy, 2005, 113 (5), 1088-1115.

Opp, Marcus M, "Tariff wars in the Ricardian Model with a continuum of goods," Journal of International Economics, 2010, 80 (2), 212-225.

Simonovska, Ina and Michael E Waugh, "The elasticity of trade: Estimates and evidence," Journal of international Economics, 2014, 92 (1), 34-50.

Uy, Timothy, Kei-Mu Yi, and Jing Zhang, "Structural change in an open economy," Journal of Monetary Economics, 2013, 60 (6), 667-682.

Ventura, Gustavo, "Flat tax reform: A quantitative exploration1," Journal of Economic dynamics and Control, 1999, 23 (9-10), 1425-1458. 


\section{A Data}

\section{A.1 Panel Survey of Income Dynamics (PSID)}

We import demographic, income, wealth and expenditure variables from PSID waves 2005 to 2015 , so that we have date for years $2004,2006,2008,2010,2012$, and 2014. We construct labor income as the sum of household wages, salaries, bonus, and tips, 50 percent of farm and business income, and employment compensation.

We restrict the sample to households whose heads are between the ages of 25 and 65 , have at least 520 (1040) work hours supplied ${ }^{11}$ for single (married) households, and have positive labor income, wealth, and tradable and nontradable consumption, which leaves us 27,918 household-year observations. We then merge in average house prices and average rent values by state and census region from the Consumer Expenditure survey, and use them to calculate home price-to-rent ratios for each state in each year. The price-rent ratios are then winsorized at the 1st and 99th percentiles. For homeowners, imputed rent is then calculated as the home value times the price-rent ratio. Total consumption is constructed as the sum of expenditures on child care, clothing, dependents, education, entertainment, food, health care, housing, transportation, and vacation, and in the case of home owners, we add imputed rent and subtract expenditures on mortgage, property taxes, home insurance, and housing repairs. Tradable consumption is constructed as expenditures on clothing, food at home, prescriptions, home furnishings, and the purchase and lease of cars and trucks. The tradable expenditure share is tradable consumption divided by total consumption.

For generating graphs, we create binned scatter plots of tradable expenditure share against wealth and income deciles. For regression analysis, we take logs of wealth and income. We perform a series of regressions with tradable expenditure share as the dependent variable. Regressors include $\log$ (wealth) and $\log$ (income), along with fixed effects on year, age, household size, college graduation status, and home ownership.

\footnotetext{
${ }^{11}$ Work hours supplied is defined as the sum of hours worked and hours in unemployment.
} 


\section{A.2 Consumer Expenditure Survey (CEX)}

From the Consumer Expenditures Survey's interview microdata, we append expenditure (mbti) files from 2004 to 2014 into one dataset. This dataset contains one entry for each expenditure by a consumer unit $(\mathrm{CU})$ in an interview period. We similarly append family characteristics (fmli) files from 2004 to 2014 into one dataset, which contains one entry for each CU. We keep wealth variables, income variables, and some demographic variables from the family files.

Using the complete expenditure dataset, we merge it with the tradability indices dataset by UCC code. We remove UCC expenditures associated with home ownership costs (mortgage interest, property taxes, home and rental insurance, and housing repairs and capital improvements) and add the CEX variable for owner-imputed rent, which we treat as a nontradable expenditure. For each household and interview period, we construct expenditures on tradables and nontradables as measured by the tradability indices, and merge this dataset with the family files.

After the merge, we restrict the sample households whose heads are between the ages of 25 and 65, have at least 400 (800) hours worked for single (married) households, and have positive labor income, wealth, and tradable and nontradable consumption, which leaves us 23,748 household-year observations.

For generating graphs, we create binned scatter plots of tradable expenditure shares against wealth and income deciles. For regression analysis, we take logs of wealth and income. We perform a series of regressions with tradable expenditure share as the dependent variable. Regressors include $\log$ (wealth) and $\log$ (income), along with fixed effects on year, age, household size, college graduation status, and home ownership. 